
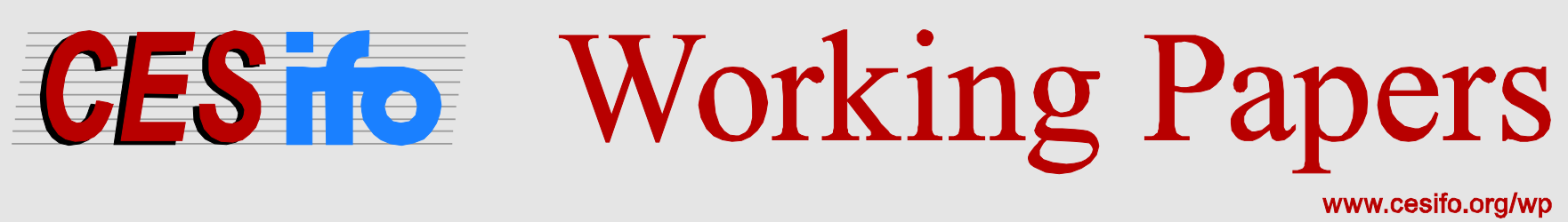

\title{
Call my Rep! How Unions Overcame the Free-Rider Problem
}

\author{
Richard Murphy
}

\section{CESIFO WORKING PAPER NO. 6362 \\ CATEGORY 4: LABOUR MARKETS \\ FEBRUARY 2017}
An electronic version of the paper may be downloaded
- from the SSRN website:
- from the RePEc website:
- from the CESifo website:
www.SSRN.com
Www.RePEc.org
www.CESifo-group.org/wp




\title{
Call my Rep! How Unions Overcame the Free-Rider Problem
}

\begin{abstract}
This paper proposes an explanation of why union membership has been increasing in some occupations, despite the opportunity to freeride on traditional union benefits. I model membership as legal insurance whose demand increases with the perceived risk of allegations. Using media reports on allegations against teachers as shocks to perceived risk, I find for every five reports occurring in a region, teachers are 2.5 percentage points more likely to be members in the subsequent year. These effects are larger when teachers share characteristics with the news story and explain 45 percent of the growth in teacher union membership since 1992.
\end{abstract}

JEL-Codes: J510, J450, J320.

Keywords: unions, teachers, media, insurance.

\author{
Richard Murphy \\ Department of Economics \\ The University of Texas at Austin \\ USA - 78712 Austin, Texas \\ richard.murphy@austin.utexas.edu
}

February 2017

I thank Alex Bryson, Claudia Hupkau, Justin Gallagher, Steve Machin, Brendon McConnell, Emma Pickering, Imran Rasul, Felix Weinhardt, the participants of the CEP Labour Workshop, CESifo Education Group, the Lancaster Departmental Seminar and the Applied Seminar at UT Austin. All remaining errors are my own. 


\section{Introduction}

Currently many US States are attempting to limit the power of unions through reducing their collective bargaining rights and membership. One example of this is the implementation of 'rightto-work' legislation, which allows individuals to work in a unionised occupation without being required to pay union dues/costs. ${ }^{1}$ Unions - being rational economic agents - are concerned that this will reduce membership demand to zero: why would employees choose to pay for membership, if they can benefit from better wages and working conditions generated through collective bargaining regardless (Freeman and Medoff 1984; Bryson and Forth, 2010)?

Yet in certain occupations, where employees have the opportunity to free ride on these benefits, union membership continues to grow. This paper provides a potential explanation for this seemingly irrational behaviour. For there to be a marginal union member, indifferent to joining and paying dues or not joining, there must exist a benefit that is unobtainable to non-members. I put forward a model of union membership as form of private legal insurance, where the decision to join is partly determined by an individuals' perceived threat of allegation being made against them. This would mean that unions could continue to exist, even if employees of that industry are not required to pay union dues.

To test the model, I apply it to the UK teacher labour market, which one could consider as an equivalent to a right-to-work 'state' since 1990 Employment Act, despite still having pay and working conditions negotiated at the national level. I use number of news stories concerning allegations against teachers originating in a region as a shock to the perceived threat of an allegation being made against all teachers in that same region. This exogenous shock measure obtained by codifying all stories relating to teachers allegations over a twenty year period occurring in national newspapers. Whilst I cannot know how many or which newspapers individuals actually read, I expect changes in the overall reporting levels to reflect general changes in perceived threat. As such, this paper adds to the growing literature on the impact of news media on individuals' expectations and decision making. These papers show that news reports on social security (van der Wiel, 2009), inflation (Carroll, 2003; Lamla and Lein 2008) and the returns to education (McGuigan et al. 2012) in period $t$ affect expectations of outcomes in period $t+1$.

\footnotetext{
${ }^{1}$ Right-to work laws ban a particular type of employment contract that requires all employees - union or not - to pay fair share provisions, to cover the costs of negotiating and enforcing their contract. There are currently 25 right-to-work states in the US, the four most recent are Wisconsin (2015), Michigan (2012), Indiana (2012), Oklahoma (2001)
} 
Using individual level union membership data from the Quartley Labour Force Surveys (QLFS) in combination with the media data, I find that unionisation rates increase with media coverage at the regional and national level. Five relevant news stories in a region increase the probability of union membership by 2.5 percentage points. Additionally, the size of the effect is dependent on the relevance of the story to the individual teacher. Teachers from secondary schools react to stories involving other secondary school teachers, there's no significant reaction to stories involving primary school teachers. Similarly, the demand for union membership increases amongst male teachers when there is news coverage concerning other male teachers, but not female teachers. Estimating the latent demand for union membership, I find that 45 percent of the growth between 1992 and 2010 was associated with increased media coverage. To get an indication of if this reflects rational behaviour by teachers, I use data on actual allegations since 2007 to calculate that at current rates the average teacher employed for 35 years has a 24 percent change of having an unfounded allegation made against them. ${ }^{2}$

The concept of union membership as a form of insurance, has been put forward by Blanchflower et. al. (1990). They model membership as an insurance against unemployment, finding that local unemployment rate has a positive impact on demand for union membership. The relationship between media reports and demand for insurance has been more recently addressed by Gallagher (2013). He finds that the demand for flood insurance increases in regions that experienced flooding in the previous year, but demand also increases in non-flooded communities that were in the same television media market as the flooded communities. This fits into the wider literature of the impact of media more generally (TV programs, radio, and movies) on a range of economic and social spheres, summarised by Della Vigna and La Ferrara (2015). Their review establishes that media has impact on education, health, crime, saving and the family, but highlights that the vast majority of this research does not concern print media. The exception being the work by Gentzkow et al (2011) showing political participation is positively impacted by print media, this paper therefore adds to this growing literature.

The main contribution of this paper is the establishment of a new source of demand for union representation, in the form of legal insurance. By doing so it illustrates that despite the outlawing of 'closed-shops' in the UK, unions in some occupations have continue to exist and flourish, by reacting to the policy landscape through offering and promoting a private and excludable service

\footnotetext{
${ }^{2}$ This actual allegations data is only available from 2007 and for a limited number of regions, therefore could not be used for the main analysis. A horserace between actual and media reported allegations on this much is presented in the Appendix Table 12. This finds that while the two measures are correlated only the media reports have a significant relationship with subsequent unionisation rate.
} 
that is growing in demand. The excludable nature of the service provides an explanation for the longstanding free rider puzzle in the union literature (Freeman and Medoff 1984) and why union density has increased in specific labour markets against a background of general decline (Neumann and Rissman, 1984; Blanchflower and Bryson, 2008). Additionally the paper contributes to the literature on media impact on decisions, by showing that individuals react more according to how similar the story is to their own situation, by exploiting the characteristics of the teachers involved in each story.

The application of this is to the demand for teacher union membership is in itself important given the impact unions have on student outcomes. Hoxby (1996) using the passage of duty-tobargain laws, finds that unions are effective at diverting funds to teachers by increasing their salaries and reducing pupil-teacher ratios. Accordingly Lovenheim and Willén (2016) estimate the long run impact of collective bargaining contracts on student's labour market outcomes. They conclude that living in a state that has a duty-to-bargain law for all 12 grade school years reduces earnings by $\$ 800$ per year and decreases hours worked by 0.5 hours per week, culminating in a total cost to the US economy of $\$ 199$ billion annually.

The policy implication is that even in a right-to-work state, the demand for union membership can still remain, and even increase, if unions provide a private service that is wanted and is not readily supplied by the private market. ${ }^{3}$ Therefore, if governments or employers want to reduce the demand for union membership, they could do so by providing more support in the workplace for staff members threatened by allegations. This would crowd out the demand for union services. An example of this observed in the data. Post a 2005 reform in the UK which restricted newspapers from report on cases before they had reached court, the number of media stories fell and so did the likelihood of union membership.

The rest of the paper is organised as follows. In Section 2, provide institutional details of teacher unions in the UK, along with anecdotal evidence of the increasing demand for unions as form of legal insurance. Section 3, formalises a model for union demand dependent on perceived threat of allegation and how it relates to the econometric specification. Section 4 describes the data sources and how the media coverage data was collected. Section 5 presents estimates of the impact of media coverage on demand for union membership, falsification exercises and explores the impact of actual versus reported allegations and Section 7 concludes.

3 There is currently no private teacher insurance market available in the UK. The possible reasons for this are discussed in Section II.C. 


\section{Institutional Detail}

This section describes the institutional setting of teacher unions in the UK, with particular attention to the validity of the key assumptions of the hypothesis.

\section{A: Union membership in the $U K$}

As with most developed countries, the UK has experienced a large decline in union membership. Total membership in 1979 stood at 13.2 million, twenty years later this had fallen to 7.9 million (DfB, 2009). This was a combination of the de-industrialisation of the economy, technological advances automating many traditional union occupations, and policy changes. During the 1980's the UK government passed a series of Employment Acts diminishing the bargaining power of unions, much of this restricted the use of 'closed-shops' where employers were compelled to employ only union members. ${ }^{4}$ This culminated in the 1990 Employment Act which made it unlawful for any workplace to exclude from employment non-union members, effectively making all workplaces 'open-shops'. A by-product of this is that a single workplace may have multiple unions present as workers may retain union membership as they move job to job. Moreover it is also possible for individuals to be members of more than one union should they choose to do so. ${ }^{5}$

This fall in union membership has occurred both across and within occupational groups, over 90 percent of occupational groups have seen a fall in union membership since 1979. However, some occupations have experienced a rise in union membership. The four occupations with the highest percentage point increases in union density since 1992 are educational assistants (28.7), secondary school teachers (12.5), primary school teachers (8.5) and the police (6.7). ${ }^{6}$ Considering teachers were already one of the most unionised occupations, makes these additional gains even more remarkable. ${ }^{7}$ In 199376.5 percent of teachers were unionised, by 2005 this had reached a

\footnotetext{
${ }^{4}$ The 1982 Employment Act banned pre-entry closed shops and closed shops were only permitted with 85 percent support. 1988 Employment Act outlaws industrial action to establish or preserve closed shops and gave union members the right to ignore strikes.

${ }^{5}$ It is typical for teachers to join multiple the teacher unions during their training period while the membership is free.

${ }^{6}$ Author's calculations based on the QLFS of all three digit occupational groups with at least 100 employees per year. The unionisation rate amongst the clergy also increased rapidly reaching a peak in 2005 of $14.3 \%$ up from a base of $2.8 \%$ in 1992 but had less than 100 observations for 5 of the 18 years.

${ }^{7}$ Educational Assistants $20.4 \%$ to $48.1 \%$, Secondary School Teachers $76.1 \%$ to $88.6 \%$, Primary School Teachers $82.3 \%$ to $90.8 \%$ and the Police $76.8 \%$ to $83.5 \%$.
} 
peak of 87.0 percent. As Figure 1 shows, this 10.5 percentage point gain was whilst the rest of the UK workforce has seen a 6 percentage point decline in union density.

These occupational groups share a common theme of employees having prolonged unsupervised interactions with vulnerable groups. Therefore the effects of society become increasingly litigious will be most acutely felt in occupations at most risk of accusations. There will likely be many repercussions on labour markets, but one rational response by employees in such occupations would be to increase their demand for insurance against these risks. ${ }^{8}$ In this paper I document the reaction in the UK teacher labour market as it is a well-defined occupational group with a large number of employees which has also had considerable press attention regarding allegations over the last two decades.

\section{B: Teacher Unions in the UK}

Teacher union representatives defend the contractual working conditions of all teachers at the school level, however negotiations regarding teacher pay, pensions, and the conditions themselves (e.g. hours worked, curriculum, pupil teacher ratios) are held at the national level. This means that it is impossible for unions to bargain only for their members, as non-union teachers employed in public sector schools will also receive any gains in benefits. Despite the possibility of being able to gain from the union negotiations, non-members are not required to pay any union dues. ${ }^{9}$ These factors make the UK teacher labour market a prime example of the trade union free-rider problem, why do teachers choose to pay the costs of union membership if pay and working conditions are determined centrally?

This puzzle is exemplified in summary statistics from the QLFS. Since 2001 all employees were asked if they thought their pay and conditions were affected by trade unions. For teachers, despite the union density being 84 percent at the beginning of this period and then increasing, the proportion of all teachers thought their union impacted pay and conditions held constant at only 75

\footnotetext{
${ }^{8}$ Some occupations are required to purchase indemnity insurance through joining a professional body. UK doctors are required to become members of the British Medical Association which is the professional association and registered trade union for doctors in the UK. Similarly for Physiotherapists and Radiologists who each have a professional body which provide including insurance cover, professional and legal advice, and support for continuing professional development (Royal College of Radiologists, and Chartered Society of Physiotherapy).

${ }^{9}$ Union dues are set by each union at a national level, in contrast to other countries where the level of dues reflect the bargaining power at the local (school/district/state) level. The annual membership fee for a full time teacher in 2015 for the two largest teacher unions in the UK were $£ 167$ NASUWT and $£ 170$ NUT, and have been constant in nominal terms since 2010.
} 
percent and then declines (See Figure 2). ${ }^{10}$ This means that some teachers are choosing to be union members even though they also think the union doesn't improve their pay and conditions.

\section{C: Unions as an insurance provider}

A rational explanation for some teachers being union members despite stating that their pay and conditions were not impacted by unions, is that teacher unions provide another benefit that is excludable to non-members. One such benefit which is highly promoted by the unions is the legal advice and protection provided in the event of an allegation being made. ${ }^{11}$ Teachers who are union members at the time of an incident and also when the allegation is made receive an official representative for the internal disciplinary meetings and legal representation if it does escalate.

The teacher trade unions consider this service to be the major driver of union demand. ${ }^{12}$ As part of the terms and conditions of membership many unions reserve the right to use the facts of successful cases to publicise their criminal representation scheme (NASUWT 2014). Moreover in a survey of teachers I conducted in 2010/11 I found that in answering the question "What were the MAIN reasons why you initially joined a teacher union?" 85 percent of the respondents stated "support in the event of allegations from pupils", compared with 56 percent saying "to improve terms and conditions" (Appendix Table 1).

There are currently no private insurance companies offering legal insurance to teachers in the UK. ${ }^{13}$ So if there is a demand for private legal insurance, why doesn't a market exist in which teachers can buy the service without the additional bundled costs involved with union membership? There are two likely reasons for this. First, were an insurer to enter into the market it would risk adverse selection of consumers. The unions currently in the insurance market have a first mover advantage, in that they have a large non-negatively selected pool of enrolees. Any entrant would not gain from the economies of scale, and if they only offered insurance would be at risk of only taking on the most costly teachers. Second, the regulations regarding internal school hearings

\footnotetext{
${ }^{10}$ One reason for not all teachers saying that their pay and conditions are affected by unions is that since the dissolution of the Burnham Committee in 1986 teacher unions no longer had a seat on the teacher pay committee. This was replaced by the School Teachers Review Body (STRB) which is made up of academics and professionals which may pay recommendations to the government. Unions can submit evidence to the STRB but do not hold a seat.

${ }^{11}$ Other excludable benefits offered by teacher unions include, continuing professional development and group discounts.

${ }^{12}$ Paddy Marshal, Head Recruitment Officer NUT stated in a phone interview in relation to the legal insurance that "the safety net is the biggest potential benefit", April 2009. Tracy Twist, Assistant General Secretary of NASUWT stated in a meeting with me that "a lot of teachers join because of these concerns".

13 Ascertained by requesting these services over the phone from the top five insurance companies (AIG, Aviva, RSA, AXA, Direct Line) in the UK, each year from 2011-16.
} 
prevent teachers from employing representation for themselves. The only forms of representations a teacher is allowed at these hearings are, themselves or a union representative/lawyer.

Teachers found guilty of one of 42 offences, such as indecent assault on a child under 16 are automatically put on List 99. This prevents the individual from ever working or volunteering to work with young people, as all organisations who deal with young people are required to check against this during the application process. In addition to criminal offences, teachers found guilty of professional misconduct can also be added to the list if deemed grievous enough, examples include falsifying qualifications and assisting students with exams. These cases are judged by the General Teaching Council (GTC), during the time period covered by this paper. The GTC would convene a panel including two teachers, one lay member and a legal representative. Teachers are able to pay for their own legal representation at hearings, but these costs are not be refunded if they were found not guilty, therefore many teachers chose to be represented by trade unions.

For fear of allegations to explain the rise in demand for union membership the threat of allegations also needs to have risen over this time period. There are no comparable records directly measuring the threat of allegations annually. However the largest union in the UK (NASUWT) reported dealing with 71 cases of alleged sexual or physical abuse in 1991, 134 in 1992 and 158 in 1993 (Independent, 1994) and then estimated dealing with 800-900 per year in 2009 (Keates, 2009). ${ }^{14}$

To obtain a more detailed and comprehensive measure of the threat against teachers, I use the number of national newspaper stories involving accusations of teachers. A detailed explanation of how this is generated is provided in Section 4. There has been a large increase in the number of newspaper stories concerning allegations against teachers over time. Figure 4 shows that between 1992 and 1998 the average per year was 6.6, this increases to 37.9 in the period 1999 to 2005. Post 2005 there was a fall in the number of news stories in national newspapers. This coincides which a change in the law which gave more protection to teachers to prevent their case being reported before a case had gone to term (HM Government, 2006). ${ }^{15}$ Therefore a basic test of the thesis would be to detect any changes in the trend of the aggregate unionisation rates which would coincide with the introduction of this policy.

\footnotetext{
${ }^{14}$ NASUWT membership over this period increased by $63 \%$ (Certification Office, 2010) whilst the number of allegations against its members increased by $1167 \%$.

${ }^{15}$ In accordance with the Association of Chief Police Officers (ACPO) guidance the police will not normally provide any information to the Press or media that might identify teacher who is under investigation, unless and until the person is charged with a criminal offence. In exceptional cases where the police might depart from that rule, e.g. an appeal to trace a suspect, the reasons should be documented and partner agencies consulted beforehand.
} 


\section{D: Actual nature of the risk}

Would a fear of allegations be rational for a teacher working in the UK today? To establish this basic tenant, I collected information on the actual allegations made against public sector employees who work with children and young people through use of the Freedom of Information Act. After contacting all 152 Local Authorities in England I received responses from 118 (See Appendix 1 for detailed list). Unfortunately it was only compulsory for Local Authorities to record this information from 2007 to 2011 and therefore the data are over a comparatively shorter period of time.

The information received contained which occupational sector the allegation was made against, and the nature of the allegation. ${ }^{16}$ The education sector received more than half of all allegations, with 52.6 percent. Of these, 56.9 percent are physical in nature and 23.9 percent sexual, which is comparable with allegations for all non-educational occupational groups with 52.5 percent and 25.1 percent respectively (Table 1). These data also provides a count of the outcomes of allegations over the previous twelve months, which I have codified into four categories; 1) Not Upheld; 2) Police Involvement; 3) Disciplinary Procedures, and 4) Referral. ${ }^{17}$ These outcomes cannot be connected to occupations, but in general 46.1 percent of all allegations are not upheld (Table 2).

To obtain a measure of relevant threat I calculated the rate of allegations per teacher per year in the responding Local Authorities using total teacher employment taken from the School Workforce in England (2011). In 2007 this was 1.49 allegations per 100 teachers per year and had amounted to 1.5 by 2010 . We can then derive an approximate objective measure of risk of a teacher having a non-upheld allegation made against them, by combining this with the figures from Table 2. Assuming that these allegations are evenly concentrated over teachers over time, and that 46.1 percent of allegations are not upheld, this means an average teacher over a career of 35 years can expect a 24.2 percent chance to have an non-upheld allegation made against them. This one in four

\footnotetext{
16 There are 15 occupational groups: Social, Care, Health, Education, Foster Carers, Connexion, Police, YOT, Probation, CAFCASS, Secure Estate, NSPCC, Voluntary Youth Organisations, Faith Groups, Armed Forces, Immigration/Asylum Support Services, and Other. There are five abuse categories: Physical, Emotional, Sexual, Neglect and Other.

${ }^{17}$ The 16 outcome categories are: Not Upheld - No further action after initial consideration, Being unfounded, Being unsubstantiated, Being malicious, Acquittal ; Police Involvement - Criminal investigation, Conviction; Disciplinary Procedures - Disciplinary Action, Suspension, Dismissal, Resignation, Cessation of use, Inclusion on barred/restricted employment list; Referral - Section 47 investigation, Referral to DCSF, Referral to Regulatory Body.
} 
chance of a non-upheld allegation provides credit towards the notion that teachers are reacting to a real threat, and not acting irrationally.

\section{Demand for Union Membership Model}

\section{A: Model and assumptions}

Teacher unions provide a unique service in the form of legal advice and protection against allegations made by students. I model union membership as form of legal insurance that teachers can chose to pay for with annual dues. The benefit is that the expected outcome in the event an allegation has been made is better if the teacher is a member of a trade union.

To formalise this decision process the following assumptions are made. There are multiple types of teachers that vary in their risk aversion, their actual risk of allegations being made against them and other characteristics that are correlated with the net benefits of union membership. All of these teacher types are summarised by a unidimensional term, $\theta .^{18}$

A teacher's utility is a function of consumption income $Y$ and type $\theta, U(Y, \theta)$, which has decreasing in marginal benefits from income. Teachers are employed in schools which are 'open shops', where union and non-union members are both employed and earn the same wages $w>0$. There is only one trade union and if a teacher decides to join the union they pay annual cost $c>0$. Therefore teacher wages can either be spent on union fees or left as consumption income, $w=Y-$ c.

If an allegation is made against a teacher they incur cost $a>c$, regardless of the subsequent outcome, reflecting the social costs and potential damage to career prospects. Similarly there is an additional cost $l$ if a teacher is found guilty of an allegation, and that $l \gg c$, reflecting the high cost of being put on List 99, or for more serious offences being imprisoned. We can now rank utilities for any given state of the world for all types $\theta$ :

$$
\begin{gathered}
U^{n}(w, \theta)>U^{u}(w-c, \theta)>U^{n w}(w-a, \theta)>U^{u w}(w-a-c, \theta)> \\
U^{n l}(w-a-l, \theta)>U^{u l}(w-a-c-l, \theta)
\end{gathered}
$$

where $U^{n}$ and $U^{u}$ are the utilities of non-members and members respectively with no allegation against them. $U^{w}$ is the utility of winning a case, $U^{l}$ is the utility of losing a case, which depend on

\footnotetext{
${ }^{18}$ Note that this allows for some types of teachers to potentially commit offences. All teachers were innocent all the time there would be no market for insurance as all teachers would be presumed non guilty.
} 
union status. For union members $U^{u w}=U(w-c-a, \theta)$, and $U^{u l}=U(w-c-a-l, \theta)$, nonunion members utilities $U^{n w}$ and $U^{n l}$ follow a similar structure, but do not incur membership cost $c$. The state with the highest utility is a non-member with no allegations against them $U^{n}$ and the worst state is a union member who lost their case $U^{u l}$.

The perceived probability of an allegation being made against a teacher with characteristics $x$ from region $j$, in year $t$, is $\delta\left(s_{x j t-1}\right)$. This an increasing function of previous news stories $s$ in the first derivative and negative in the second, reflecting the diminishing marginal impact of the news stories in a region. ${ }^{19}$

The probability of a teacher being exonerated is $r(x)$ which is increasing in the amount of resources devoted to their defence $x$. Therefore expected utility of a teacher once an allegation is made, $Z$, is a convex combination of winning and losing utilities given their union membership status.

$$
\begin{aligned}
& Z^{n}=r\left(x^{n}\right) U^{n w}+\left(1-r\left(x^{n}\right)\right) U^{n l} \\
& Z^{u}=r\left(x^{u}\right) U^{u w}+\left(1-r\left(x^{u}\right)\right) U^{u l}
\end{aligned}
$$

The individual teacher has only one decision to make: whether to join the union or not. The marginal individual of type $\theta^{*}$ is indifferent between joining a union or not, when there are no marginal benefits of joining, $b=0$.

$$
\begin{gathered}
b=E U(\text { membership })-E U(\text { nonmembership })=0 \\
b=\left[\delta(s) Z^{u}+(1-\delta(s)) U\left(w-c, \theta^{*}\right)\right]-\left[\delta(s) Z^{n}+(1-\delta(s)) U\left(w, \theta^{*}\right)\right]=0
\end{gathered}
$$

As $U\left(w-c, \theta^{*}\right)<U\left(w, \theta^{*}\right)$, and the perceived probability of an allegation is the same for an individual regardless of membership status, means that the expected utility once an allegation is made for a union member, must be is greater than for a non-union member $Z^{u}>Z^{n}$. This provides the first implication of the model. Since the only difference between $Z^{u}$ and $Z^{n}$ comes from $r(x)$, we must have that for unions to have any members we need that unions provide more resources in for defence $r\left(x^{u}\right)>r\left(x^{n}\right)$. This result reflects the restrictions that exist for teachers in employing private representation, making it difficult to transform income into defensive resources efficiently.

${ }^{19}$ The perceived threat can also be a function of other factors in addition to news stories, such as the actual number of allegations. Section 5.4 investigates the use of this other less salient measure of threat. Results imposing a linear relationship between news stories and the decision to join a union provide qualitatively similar results. 
Taking the first derivative of (2) with respect to the number of news stories, it can also be shown that the expected gain from membership for the marginal member is an increasing function of news reports.

$$
\begin{gathered}
\frac{d b}{d s}=\left[\delta^{\prime}(s) Z^{u}-\delta^{\prime}(s) U\left(w-c, \theta^{*}\right)\right]-\left[\delta^{\prime}(s) Z^{n}-\delta^{\prime}(s) U\left(w, \theta^{*}\right)\right] \\
=\delta^{\prime}(s)\left(Z^{u}-Z^{n}\right)+\delta^{\prime}(s)\left[U\left(w, \theta^{*}\right)-U\left(w-c, \theta^{*}\right)\right]
\end{gathered}
$$

Given the assumptions that $\delta^{\prime}(s)>0, Z^{u}-Z^{n}>0$ and $\left(w-c, \theta^{*}\right)<U\left(w, \theta^{*}\right)$, then it

follows that $\frac{d b}{d s}>0$. For an indifferent teacher with taste for risk $\theta^{*}$, the marginal benefit of unions is increasing the number of news stories.

\section{B: Comparative Statics}

I now present comparative statics to illustrate the case of a teacher of type $\theta^{*}$ would chose to be a union member when the perceived risk of an allegation is high, but choose not to when the perceived risk is low.

Panel A of Figure 3 shows her utility function $U\left(Y, \theta^{*}\right)$, and the utility levels specified in (1). A teacher will make their decision about joining a union by evaluating their utility if no allegations are made, their expected utility if an allegation is made, and the probability of that allegation being made in the first place. The expected utility of a union member once an allegation has been made, is represented by the chord linking the points $U^{u l}$ and $U^{u w}$ (similarly for the points $U^{n l}$ and $U^{n w}$ for non-members). The exact point on the chord is determined by the probability of success, $r(x)$. As $r\left(x^{u}\right)>r\left(x^{n}\right)$, the union member will be higher up their chord than the non-union member, and so we can plot $Z^{u}>Z^{n}$.

A (non)union teacher will compare their outcomes should no allegation be made $U\left(w-c, \theta^{*}\right)$ $\left(U\left(w, \theta^{*}\right)\right)$ to their expected utility in the event of an allegation $Z^{u}\left(Z^{n}\right)$. Therefore the expected utility before an allegation is made is a combination of these two outcomes. These combinations for union and non-union members can be seen in Panels B and C of Figure 3. The lower chord that links the intersection of the utility curve with $Z^{n}$ to the intersection with $w$, represents the expected utility space of a teacher who is not a union member. Similarly, before an allegation is made, a union teacher is at a point on the upper chord between $U\left(w-c, \theta^{*}\right)$ and $Z^{u}$.

The point at which a teacher is along this new chord is dependent on their expectations of an allegation being made against them. Panel B of Figure 3 shows a high threat scenario, $\delta(s)=0.5$, 
and the individual will be at the midpoint of each chord. With this high perceived threat level we can see that the expected utility from membership is greater than that of non-membership, $E U^{u}>$ $E U^{n}$. In contrast Panel $\mathrm{C}$ shows the same teacher with the same taste for risk and type $\theta^{*}$ and same amount of union dues $c$, would chose not to be in a union if the risk level was low $\delta(s)=0.1$.

This basic example demonstrates that the demand for union membership is directly related to the perceived threat of allegations, $\delta\left(s_{x j t}\right)$. When there is a low probability of an allegation being made, the cost of union membership outweighs the gains through better representation if an allegation was to occur and so teachers will not join the union.

\section{Econometric Specification}

This basic model of rational decision making by the teacher forms the basis of the estimation strategy. It stated that teacher $i$ from region $j$ in time period $t$ will choose to join the union if the expected benefits of joining the union are positive, $E U_{i j t}^{u}-E U_{i j t}^{n}>0$. Each of these expected utilities will be a function of many factors in addition to perceived threat of an allegation being made and will be related to the teachers type $\theta$. This can be summarised by the two following equations.

$$
\begin{aligned}
& E U_{i j t}^{u}=\alpha^{u}+\rho^{u} \delta\left(s_{j t-1}\right)+\gamma^{u} X_{i j t}+\mu_{j}^{u}+\omega_{t}^{u}+\varepsilon_{i j t}^{u} \\
& E U_{i j t}^{n}=\alpha^{n}+\rho^{n} \delta\left(s_{j t-1}\right)+\gamma^{n} X_{i j t}+\mu_{j}^{n}+\omega_{t}^{n}+\varepsilon_{i j t}^{n}
\end{aligned}
$$

where $\delta\left(s_{j t-1}\right)$ is the perceived threat in region $j$ in time period $t$ caused by news stories $s$ in the previous period. $\rho^{u}$ is the expected benefits for a union member per unit of perceived threat The remaining parameters account for the other characteristics of a teacher type $\theta \cdot \alpha^{u}\left(\alpha^{n}\right)$ is the general benefits for being a (non)union member for all individuals in all time periods. $X_{i j t}$ is a vector of observable individual characteristics which affect the perceived benefits, such age, qualifications, sector of employment and gender. The additional gains for being a union member in region $\mathrm{j}$, are represented by $\mu_{j}^{u}$ are this could reflect taste for unions in a particular region. $\omega_{t}^{u}$ allows for differential gains from union membership each year, which impacts all teachers in in the same way, such as any general fall in union power. Individuals also have an idiosyncratic taste for (non)union membership which varies overtime, $\varepsilon_{i j t}$. The probability that individual $i$ in region $j$ at time period $t$ will be a trade union member is $\operatorname{Pr}\left(E U_{i j t}^{u}>E U_{i j t}^{n}\right)$, using the standard result (McFadden, 1976) we can combine equations 5 and 6 into the following 


$$
\operatorname{Pr}\left(E U_{i j t}^{u}>E U_{i j t}^{n}\right)=\frac{\exp \left(\alpha+\rho \theta\left(s_{j t-1}\right)+\gamma X_{i j t}+\mu_{j} \text { Region }_{j}+\omega_{t} \text { Year }_{t}\right)}{1+\exp \left(\alpha+\rho \theta\left(s_{j t}-1\right)+\gamma X_{i j t}+\mu_{j} \text { Region }_{j}+\omega_{t} \text { Year }_{t}\right)}
$$

where each parameter is now the marginal benefit for individual $i$ to join the union $\left(\rho=\rho^{u}-\rho^{n}\right)$. As I do not have a measure of perceived risk, only the incidence of media stories, I am not able to separately identify the perceived threat from each story $\delta$ and the marginal gain $\rho$ from a unit of perceived threat. Instead I will be estimating the combination of the two, the expected marginal gain for union members per story. Given that by assumption $\delta\left(s_{j t-1}\right)$ is decreasing, this will parameterised into the effect per story $\beta_{1}$, and it's square $\beta_{2}$. The demand for union membership can then be estimated using a logistic regression, where the parameters of interest are $\beta_{1}+2 \beta_{2} \overline{S_{J t-1}}$ representing the marginal effect of an additional story at the mean news coverage on union membership.

$$
U_{i j t}=\alpha+\beta_{1} s_{j t-1}+\beta_{2} s_{j t-1}^{2}+\gamma X_{i j t}+\mu_{j}+\omega_{t}+\varepsilon_{i j t}
$$

where $\mathrm{U}$ is an indicator variable if individual $i$ in period $t$ is a union member or not and $s_{j t-1}$ is the number of stories in region $j$ in time period $t$ - 1 . I include a series of regional and year fixed effects, $\mu_{j}$ and $\omega_{t}$ respectively. This specification assumes that media coverage of region $\mathrm{j}$ as no impact on the perceived benefits of union membership in a different region. ${ }^{20}$ To allow for spill-overs and to obtain estimates of the total impact of news stories on union membership, I will estimate an alternate specification which additionally includes a measure for total news stories nationally each year, $s_{t}$ and replace the year effects term with a time trend.

$$
U_{i j t}=\alpha+\beta_{1} s_{j t-1}+\beta_{2} s_{j t-1}^{2}+\beta_{3}{ }^{N a t} s_{t-1}+\beta_{4}{ }^{N a t} s_{t-1}^{2}+\gamma X_{i j t}+\mu_{j}+\varphi Y e a r_{t}+\varepsilon_{i j t}
$$

Following similar reasoning that teachers are more likely to be affected by news stories originating in their region, one may expect certain stories to have a larger impact on certain teachers who share characteristics with the teacher involved in the media coverage. For example, a news story involving false allegations against a male teacher may be more relevant to other male teachers compared to female teachers. I investigate this by allowing the threat to vary by the characteristics of the teacher in the story $s_{x j t}$ and estimate the impact when the characteristics of the teacher are the same or different to the characteristics of the story, $X_{i j t}=X_{s j t}$ and $X_{i j t} \neq X_{s j t}^{\prime}$. Any differences in the effect may be due to the threat that a given story generates is greater, $\delta\left(s_{x j t-1}\right)>$

\footnotetext{
${ }^{20}$ The standard errors throughout the paper are clustered at this regional level.
} 
$\delta\left(s_{x^{\prime} j t-1}\right)$ when $X_{i j t}=X_{s j t-1}$ and $X_{i j t} \neq X_{s j t-1}^{\prime}$ or the expected marginal gain driven by the story is larger $\left(\rho_{X_{i j t}=X_{s j t-1}}>\rho_{X_{i j t} \neq X_{s j t-1}}\right)$. Again, I cannot separately identify these effects but will instead estimate the marginal effect of a similar or less similar story.

$$
\begin{aligned}
& \text { Union }_{i x j t}=\alpha+\beta s_{i x j t-1}+\beta s_{i x j t-1}^{2}+\gamma X_{i j t}+\mu_{j}+\omega_{t}+\varepsilon_{i j t} \\
& \text { Union }_{i x j t}=\alpha+\beta s_{i x^{\prime} j t-1}+\beta s_{i x^{\prime} j t-1}^{2}+\gamma X_{i j t}+\mu_{j}+\omega_{t}+\varepsilon_{i j t}
\end{aligned}
$$

\section{Data and Descriptive Statistics}

\section{A Union Membership Data}

Information on teachers and their union status is obtained from the UK Quarterly Labour Force Surveys (QLFS) over the period 1992 through 2010. The QLFS is conducted by the Office of National Statistics and follows approximately 60,000 households every quarter. Individuals are asked for employment and personal characteristics. This allows me to condition on factors that have been shown to be important determinants of union status (Machin, 2006); age, tenure, gender, region, occupation, public sector employee, qualifications and region. Information relating to union membership is only collected in the autumn quarter and so only observations from this quarter can be used. ${ }^{21}$ The estimates are generated over the period 1993 to 2010, as some individual characteristics are not available in 1992.

Teachers are identified through three digit occupation codes, which allows teachers who work in Primary Schools, Secondary Schools and Special Schools to be separately identified. This results in a final sample used for estimation of 30,392 teachers, with on average 1,782 teachers per year, 827 of which teaching at Primary Schools and 817 teaching at Secondary Schools. Summary statistics on teachers in comparison to the workforce in general can be found in Table 3. As one may expect the teacher labour market is considerably different, $88.6 \%$ are employed in the public sector compared with 24.6 percent in the wider economy. Moreover the teacher population is also more female (72.5 percent versus 47.5 percent) and has a higher proportion of graduates (74.3 percent versus 18 percent).

\footnotetext{
${ }^{21}$ As the QLFS is a continuously rotating panel of households interview over five quarters and information relating to union membership is obtained every autumn, a quarter of individuals are asked twice about their union status. Unfortunately the number of repeated teacher observations is too small to run auxiliary analysis on this sample. The standard errors are clustered at the regional level and no teacher in the sample is observed changing regions between surveys.
} 
Regarding the main characteristic of interest, the unionisation rate of teachers is 84 percent compared with 27.6 percent for non-teachers and 59.4 percent in the public sector as a whole. This paper uses the twenty detailed Government Office Regions as the region of analysis, which is derived from Local Authority residence. These larger regions allow for news stories to have wider impacts outside of their immediate vicinity. ${ }^{22}$

\section{B. Media Coverage}

Many different factors may influence the perceived threat of an allegation being made against a teacher. This paper uses the impact of media coverage originating in the region teacher $i$ is a resident of as an indicator for overall threat. In order for this to be exogenous, requires two assumptions. First, that there is no moral hazard on the behalf of teachers, individuals are not more likely to commit an offence if they are a union member. Second, that areas with high union density are no more likely to generate news stories. This assumption is tested by means of an event study in the robustness section.

It would be very difficult to have a measure of all news coverage e.g. television programmes, news websites, newspapers and magazines. Therefore, similar to other papers (Carroll, 2003; Lamla and Lein, 2008; van der Wiel, 2009) I will be using the number of articles in national newspapers as a proxy for all media coverage. The data on news stories is obtained from LexisNexis, an online database of media published in the UK. In order to have a consistent measure of press coverage, only newspapers that were present in LexisNexis throughout the entire period were used for the analysis. ${ }^{23}$ I searched for all articles which contained the word 'teacher' in the headline and included any of the following terms (or derivatives) in the headline or main text; teacher, damages, sued, litigation, allegation, jail, court, dismissed or fired, over the period September 1991 to August 2010. Using the date of the QLFS interview and media publication date, I allocate media coverage from the twelve months prior to the interview to the teacher. The length of this recall period is varied in the robustness section.

Each of these news stories were categorised by a pre-defined rubric. This coding frame classified news stories into four levels according to how relevant they would be to influence a teacher's perceived benefit of joining a union; Extremely Relevant (e.g.teacher found innocent and

\footnotetext{
${ }^{22}$ Use of the restricted access QLFS with Local Authority information is not possible before 2002 as these files have been converted to the new calendar framework and as union questions were only asked in the Autumn were removed from files.

${ }^{23}$ Newspapers that were omitted due to only appearing for part of the sample period were: The Morning Star, The Express, The Daily Telegraph, Sunday Express, Sunday Telegraph, The News of the World, The People. Their inclusion does not change the interpretation of the results.
} 
case thrown out of court); Highly Relevant (e.g. a teacher currently on trial); Little Relevance (e.g. Guilty of a lesser offence/on trial strong evidence); Not Relevant (e.g. Teacher admits guilt of extreme sexual abuse). A full description of the categories can be found in Appendix Table 2. Note, it is possible that a single case can appear in different levels as the newspaper stories develop over time. In total 1709 stories were coded, of which 623 were classified as extremely relevant and a further 548 as highly relevant.

The newspaper stories are further categorised by story type according to if they involve: Allegations, Being Sued, Suing, Being Attacked, Criminal Activity, Being Sacked, Employment Tribunal and Teacher Union Activity. For the main analysis I define an accusation story as by the following story types 'Allegations', 'Being Sued', and 'Criminal Activity', with parallel analysis using all story types. The total number of stories of this type in the balanced panel of newspapers that are extremely or highly relevant are 439 . Table 4 summarises the total number of stories by level and type. Figure 4 shows the large increase in the number of news stories since the late 1990's, alongside the growth in union density.

In addition to the relevance and region of the news stories, I also extracted information on the type teacher involved in the story. The name of the teacher, or pronoun used in each story was used to determine the gender of the teacher. References to the school name or the age of the pupils involved determined if the teacher was teaching in a Primary or Secondary school. In this way I was able to assign gender in $96.6 \%$ of stories and school level in $82.4 \%$ of stories. For stories where the gender or school level of the teacher were not mentioned, the story was not counted for either group. Stories relating to trade unions or where no region is mentioned are only counted towards the total number of stories nationally. Stories involving secondary school teachers are the most common representing $66.3 \%$ of highly relevant stories. The balance between the genders is more equal with $50.7 \%$ of highly relevant stories involving male teachers and $46.5 \%$ involving female teachers (Table 5).

\section{Results}

\section{A. Aggregate Trends}

Between 1993 and 2005 the union density amongst teachers increased by 10.5 percentage points, whilst amongst non-teachers it fell by 6 percentage points (Figure 1). This increase in unionisation rate has occurred across all teacher age groups, which implies that this growth rate is not solely due to improvement in recruitment rates amongst newly qualified teachers but a general 
demand in union membership across all teaching age groups (Appendix Figure 1). Union density started to decline after the government restriction on media reporting in 2005. This decline was not reversed with the increase in unemployment rate associated with the great recession form 2008 onwards. This is in contrast to the Blanchflower et. al. (1990) who also model union membership as a form of insurance, but in their case against unemployment. They find local unemployment rate to has a positive impact on demand for union membership, however these aggregate trends are indicative that this is not the main driver of union membership amongst teachers during this period.

\section{B. Main Results}

We now turn to analyse the aggregate trends of Figure 4 through the regression framework developed in Section III. The basic estimating equation is given by specification (8). I use the number of national news stories that originated in a region from the previous twelve months, as a shock to the perceived threat of an accusation being made. These within region logistic estimates are presented in Table 6. To aid interpretation these have been transformed from the logistic parameters to the marginal effect multiplied by 100 and so can be thought of as percentage change in probability. ${ }^{24}$

Column 1 of Panel A shows a positive significant raw correlation of 0.548 between the number of Extremely Relevant stories involving an accusation in a region on the likelihood of union membership. Column 2 conditions on individual characteristics, with little change in the coefficient which implying that there is little correlation between the incidence of news stories and these characteristics (0.588). Column 3 additionally allows for varying union demand in each region, and is therefore using the within region variation in news stories over time. The final column additionally includes year effects which allows for the average unionisation rate to increase over time, which is the smallest of the estimates at 0.498 but remains significant at the 5 percent level.

The quadratic term is negative and significant, implying that each additional story beyond the first has a smaller impact. Evaluating the marginal effect at the mean, I find that each additional highly relevant story increases the probability of being a union member by 0.428 . Panel B shows the same specifications on the same sample, but uses both extremely and highly relevant stories,

${ }^{24}$ Original estimates of the logit parameters available upon request. The parameters are transformed by $\mathrm{P}(\widehat{\text { Unıon }}) *(1-\mathrm{P}(\widehat{\text { Unıon }}))$, changing them from odds ratios to probabilities at the mean. 
instead of just the most relevant. As one may expect the marginal impact is smaller, at 0.380 , but remains significant. ${ }^{25}$

One may be concerned that these effects could be generated from random fluctuations in the number of news stories by region. Therefore as a robustness check Panel $\mathrm{C}$ of Table 6 estimates the impact of stories of Little to No Relevance on union membership. Reassuringly I find that the incidence of these stories have no impact on union demand.

These would not capture the total impact of news stories annually on national membership, as I am using the annual variation at the regional level whilst accounting for national year effects. To obtain a national impact I replace the 17 year effect terms with a single year trend variable. Total number of stories nationally per year reflects the additional growth due to media coverage over the long run unionisation trend. The corresponding estimates are found in Table 7. The number of the most relevant stories nationally has an additional impact above and beyond the number of regional stories. The impact is smaller than the regional impact (0.108, versus 0.481$)$. Using the average number of stories locally and nationally I can calculate the mean total effect of newspaper stories on union demand. Compared to years with no relevant news stories, the mean number of stories in the past year increases the probability of union membership by 1.46 percentage points.

\section{Media Impact by Relevance of Coverage}

The model describes a teacher's decision process in choosing to become a teacher, highlighting the roll of the threat of allegation driven by news stories, on the marginal benefit of joining the union. If a teacher shares more characteristics with the teacher in the story one may expect that the story is more relevant in their updating process.

Table 8 presents results according to the school type of the teacher works for (Primary School, Secondary School) and by the school type reported in the media. To simplify the table I report the final marginal impact of stories, conditioning on individual characteristics, year and regional effects (original estimates appear in Appendix Table 3). Column 1 uses the subsample of Secondary School teachers, and Column 2 the subsample of Primary School teachers. The top panel estimates the impact of all relevant news stories, and shows that secondary school teachers react to media coverage but there is no significant reaction from primary school teachers. This coincides with there being more relevant stories involving secondary school teachers (balanced panel of relevant

\footnotetext{
${ }^{25}$ I have run a parallel set of estimations which instead use a measure of news impact, derived from the number of words per story normalised by mean story length in that newspaper in in that year. These results mirror these findings and are available upon request.
} 
news: 285 Secondary stories, 90 Primary stories; Table 3). The lower two panels, Panels B and C, instead use only the stories involving Secondary and Primary School teachers respectively. I find that demand for union membership amongst Secondary School teachers significantly reacts to stories involving other secondary school teachers $(0.907)$ but not to stories involving Primary School teachers (0.131) (Column 1). For Primary School teachers neither effects are statistically significant, however the coefficient relating to Primary School stories is higher than the one for secondary schools.

These results are replicated in columns 3 and 4 which instead uses all relevant news stories, not just those relating to accusations. As before this produces similar results to the highly relevant stories, in which secondary school teachers react more in general and react more to secondary school stories than those set in primary schools. With this broader news story definition I now find a marginally significant effect of Primary news stories on Primary School teachers.

Table 9 has the same structure as Table 8 but focuses on the similarity of the teachers' gender to that of the story. Here we see that only female teachers react significantly to relevant news stories in general. This could be indicative of female teachers being more risk averse in their type $\theta$, so for any given increase in perceived threat, the increase in demand for insurance would be larger. Once we examine the impact by story type, male teachers do significantly react to news stories involving other male teachers $(0.591)$ but not to those relating to female teachers $(-0.056)$. Female teachers also react more to stories involving male teachers rather than female teachers $(0.897$, 0.386). One possible explanation for this results is that female teachers, despite ostensibly having more in common with other female teachers mentioned in the press, may associate the incidence of false allegations to be higher in cases involving men and therefore react more to these types of stories. These findings are repeated using all story types (Columns 3 and 4), rather than those just relating to accusations against the teacher and produce similar results.

\section{Media Impact on Other Occupations}

As a robustness check that these reports are reflecting a change to the perceived threat to teachers and not to general union demand. I now estimate the impact of news stories on individuals from other related occupations, and unrelated occupations. Table 10 shows the impact of these stories on occupations that are increasingly less similar to teachers; educational assistants, higher education professionals, non-teacher public sector graduates, and non-teacher graduates. The coefficients of interest are not significant for any of the other occupational groups. However there is indicative evidence of an effect on education assistants which has a larger marginal effect at the mean compared to the teachers, but is insignificantly determined (0.622 versus 0.428$)$. Moreover, 
the marginal (insignificant) effects decrease in size as the occupations become less similar to teachers, with the effect of teacher news stories being a tenth of the size on non-teacher graduates in general.

\section{E. Long Run Media Impact}

All the estimates presented thus far have been estimating the impact of media coverage that occurred in the twelve months prior to the interview, thereby restricting the impact of news that occurred before this time to have no influence on an individual's decision. This section will vary the exposure length to examine the fade out of these media effects on union membership. Moreover as a robustness test against the possible endogenous media reporting, I will check news stories that have yet to occur influence predict unionisation rates.

Table 11 presents the impact of regional highly relevant media in six month periods up to 36 months before the survey interview. I find that individuals react in a similar way to stories from the last six to twelve months, and effects continue to exits from stories that happened between a year and eighteen months ago, but stories prior to that have not significant impact. This implies that for those marginal members who were otherwise indifferent to joining, being a union member is not an absorbing state. Alternatively, it could be interpreted that if a potential union member hasn't joined within the first eighteen months of a story being published then that story is not going to impact on their decision. ${ }^{26}$

One can imagine if there are more union members in an area there is an increase likelihood of moral hazard by the teachers, or that the union has more members from which to generate media stories and publicity. To test whether news stories are endogenous to union membership, Figure 5 presents an event study showing the impact of news stories occurring up to thirty months into the future and past. We again see past news stories on the current likelihood of union membership, but stories that have yet to occur have no significant impact.

As we have seen that there are effects of news stories up to eighteen months beforehand, I now estimate the total impact of media coverage on union membership over time. Allowing for separate effects for the amount of news stories in each six month period up to thirty six months prior to the QLFS interview, both nationally and regionally, I predict the probability of union membership for the years between 1993 and 2010. These estimates are plotted in Figure 6. The model is a good fit

\footnotetext{
${ }^{26}$ Appendix Table 5 shows the impact of extending the period of analysis out from six months out to thirty months in six month steps.
} 
as these predicted probabilities fit very closely to the plotted series of actual union density, rarely diverging from the $95 \%$ confidence interval band. This model provides a better fit to the data in comparison to a specification that omits perceived threat parameters. This series is also plotted in Figure 6 and fails to reflect the growth in density from 1998 and the fall that occurred post 2005, the year in which new regulations were introduced that made it harder to report on stories before they arrived to court.

To estimate the aggregate impact the increased perceived threat has had on union membership, I use these estimates re-predict union membership for each year, but fix the total news coverage to zero. This provides a counterfactual time series of what would have occurred had there been no increase in the threat of allegations. The figure shows that without media coverage the union membership would have been relatively stable at around 81 percent from 1996 onwards, in contrast to it steadily rising and reaching a peak of 87.5 percent. In the period from 1999 through to 2009 the probability of union density is significantly greater than estimates where there was no media coverage. Between 2002 and 2008 this estimated difference in union membership is 5 percentage points. $^{27}$

\section{Conclusions}

This paper examines the role of the threat of accusations has had in the demand for trade union membership amongst teachers in the UK. I have found that teachers from regions in which news stories concerning accusations against other teachers originated, are more likely to join a union in the following eighteen months. For every ten stories in a region a teacher is 5 percent more likely to join. These effects are larger if teachers share characteristics with the teacher mentioned in the story, e.g. secondary school teachers react more to stories involving other secondary school teachers, similarly for male teachers. I show that the impact of stories are again larger the more relevant they are to an innocent teacher. In contrast occupations that a less like teachers do not react to these stories.

\footnotetext{
${ }^{27}$ The paper uses media coverage as the determinant of the threat of an accusation alternatively, it may be the case that these news stories reflect a growing number of actual allegations. Using the data on the actual allegations, over a shorter time period with fewer regions, I find a positive correlation between news stories and allegations. However, in a horserace between these two on this much reduced sample (3,399 obs) only news stories are significant.
} 
The model accurately predicts the changes in union membership since 1993. Setting media stories to zero throughout the period, I forecast that union membership would remain steady at approximately 81 percent rather than increasing to 87 percent as seen in the data, and as such accounts for 45 percent of the growth in union density since 1992.

This paper provides evidence as to why the individuals choose to join a trade union even if they have to opportunity to free ride the traditional benefits of union membership, such as higher pay and working conditions. Unions offering a private excludable service can maintain demand for membership, as long as demand for that service remains. The implication for policy is that introduction of 'right to work' legislation will not necessarily reduce demand for union membership to zero. In addition there may be an increasing unmet demand for union membership in previously under-unionised service sectors. Finally, if regulations are introduced that protect individuals from allegations, then the demand for union services, and hence membership, will decline. Suggestive evidence for this can be seen in the fall in union density post the 2005 governmental reforms on newspaper reporting, which continued to fall despite the worsening of economic conditions, which is traditionally thought of as a key driver of union demand. 


\section{References}

Blanchflower, D. and Bryson. A. (2008). Union Decline in Britain, IZA, Discussion Paper 3436, April 2008

Blanchflower, D. Crouchley. R. Estrin, S. and Oswald, A., (1990). Unemployment And The Demand For Unions, Centre for Labour Economics, Working Papers 372, London School of Economics.

Bryson. A. and Forth J. (2010). Trade Union Membership and Influence 1999-2009. Centre for Economic Performance, Discussion Paper 1003.

Chartered Society of Physiotherapists. (2013). Last accessed 27 May 2015, http://www.csp.org.uk/membership/membership-benefits

Carroll, C. D. (2003), Macroeconomic Expectations of Households and Professional Forecasters, Quarterly Journal of Economics, 118(1), pp.269-298.

Della Vigna S. and La Ferrara E. (2015) Economic and Social Impacts of the Media. NBER Working paper 21360

Department for Business Enterprise \& Regulatory Reform. (2009). Trade Union Membership 2008, Office of National Statistics

Department for Education, 2012, School workforce in England: November 2011, Last accessed 27 May 2014, https://www.gov.uk/government/publications/school-workforce-in-england-november2011

Freeman, R. B. and Medoff. J. L. (1984). What Do Unions Do? New York: Basic Books, 1984

Gallagher, J. (2014). Learning about an Infrequent Event: Evidence from Flood Insurance Take-up in the US, American Economic Journal: Applied 6(3): 206-33 .

Gentzkow, M, Shapiro, J.M. and Sinkinson, M (2011) "The Effect of Newspaper Entry and Exit on Electoral Politics." American Economic Review, 101(7): 2980-3018.

HM Government. (2006). Working Together to Safeguard Children. The Stationery Office.

Hoxby, C. (1996) "How Teachers' Unions Affect Education Production." The

Quarterly Journal of Economics 111(3): 671-718.

Keates C, (2009), General Secretary of NASUWT interview on "File on Four" BBC Radio 4, April 2009. 
Lamla, M. and Lein, S. (2008), The Role of Media for Consumers' Inflation Expectation Formation, KOF Working Papers 201, KOF Swiss Economic Institute.

Lovenheim, M. and Willén (2016) "The Long-run Effect of Teacher Collective Bargaining on Educational Attainment and Labor Market Outcomes” CESifo Working Paper Series 5977, CESifo Group Munich

McMuigan. M. McNally. S. and Wyness G. (2012). Student Awareness of Costs and Benefits of Educational Decisions: Effects of an Information Campaign, Centre for Economic Performance, Discussion Papers 139

Murphy, R. (2011). Impact of UK Resilience Programme training on Staff. Hertfordshire Council, Programme Report.

NASUWT. (2006). "Legal Assistance Scheme: Alleged Criminal Offence”, NASUWT Terms and

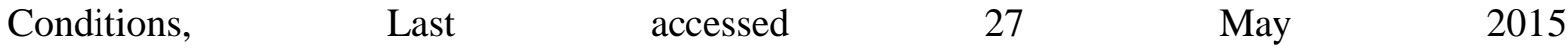
http://www.nasuwt.org.uk/consum/groups/public/@legalandcasework/documents/nas_download/ nasuwt_000791.pdf

Neumann. G. R., and Rissman E.R. (1984). Where Have All the Union Members Gone? Journal of Labor Economics, Vol. 2, No. 2, Essays in Honor of Melvin W. Reder (Apr., 1984), pp. 175-192.

van der Wiel, K. (2009). Have You Heard the News? How Real-Life Expectations React to Publicity, IZA Discussion Papers, 4064, Institute for the Study of Labor

Viscusi, W. K. and Hakes, J.: 2008, Risk Beliefs and Smoking Behavior, Economic Inquiry 46(1), pp 45-59. 
Table 1: Allegations by Employer and Type of Allegation

\begin{tabular}{lcccccc}
\hline \hline & \multicolumn{7}{c}{ Type of Allegation } & & \\
Panel A: All Reporting Local Authorities 2007-2011 & & & & Total \\
Employer & Physical & Emotional & Sexual & Neglect & Other & T, \\
\hline Education & 6,267 & 932 & 2,642 & 316 & 862 & 11,019 \\
Foster Carers & 1,512 & 305 & 388 & 255 & 70 & 2,530 \\
Social Care & 1,085 & 169 & 356 & 176 & 112 & 1,898 \\
Secure Estate & 384 & 15 & 26 & 0 & 6 & 431 \\
Health & 257 & 42 & 177 & 66 & 41 & 583 \\
Voluntary Youth Organisations & 203 & 34 & 342 & 23 & 48 & 650 \\
Faith & 177 & 8 & 96 & 1 & 12 & 294 \\
Police & 142 & 33 & 72 & 9 & 12 & 268 \\
Immigration & 39 & 2 & 39 & 6 & 0 & 86 \\
Connexions & 14 & 4 & 14 & 3 & 5 & 40 \\
Youth Offending Teams & 10 & 8 & 19 & 6 & 9 & 52 \\
Armed Forces & 6 & 0 & 25 & 1 & 0 & 32 \\
Probation & 5 & 0 & 2 & 1 & 0 & 8 \\
NSPCC & 4 & 1 & 2 & 0 & 1 & 8 \\
CAFCASS & 1 & 2 & 2 & 1 & 1 & 7 \\
Other & 1,380 & 247 & 941 & 233 & 247 & 3,048 \\
\hline Total by type & 11,486 & 1,802 & 5,143 & 1,097 & 1,426 & 20,954 \\
\hline
\end{tabular}

Source: Freedom of Information Requests to English Local Authorities

Note: Lists of responding Local Authorities and balanced Panel of Local Authorities is in Appendix 1

Table 2: Total Recorded Outcomes of Allegations

\begin{tabular}{|c|c|c|c|c|c|}
\hline \multirow{2}{*}{\multicolumn{6}{|c|}{ Panel A: All Reporting Local Authorities 2007-2011 }} \\
\hline & & & & & \\
\hline & Not Upheld & $\begin{array}{c}\text { Police } \\
\text { Involvement }\end{array}$ & $\begin{array}{l}\text { Disciplinary } \\
\text { Procedures }\end{array}$ & Referral & Total \\
\hline Total & 4,680 & 1,030 & 3,058 & 1,373 & 10,141 \\
\hline Percent of total & $46.1 \%$ & $10.2 \%$ & $30.2 \%$ & $13.5 \%$ & \\
\hline
\end{tabular}

Source: Freedom of Information Requests to English Local Authorities

Notes: Not Upheld - No further action after initial consideration, Being unfounded, Being unsubstantiated, Being malicious, Acquittal ; Police Involvement - Criminal investigation, Conviction; Disciplinary Procedures - Disciplinary Action, Suspension, Dismissal, Resignation, Cessation of use, Inclusion on barred/restricted employment list; Referral - Section 47 investigation, Referral to DCSF, Referral to Regulatory Body. Total outcomes do not equal total number of cases as not all cases had an outcome in the last 12 months. 
Table 3: Employee Summary Statistics

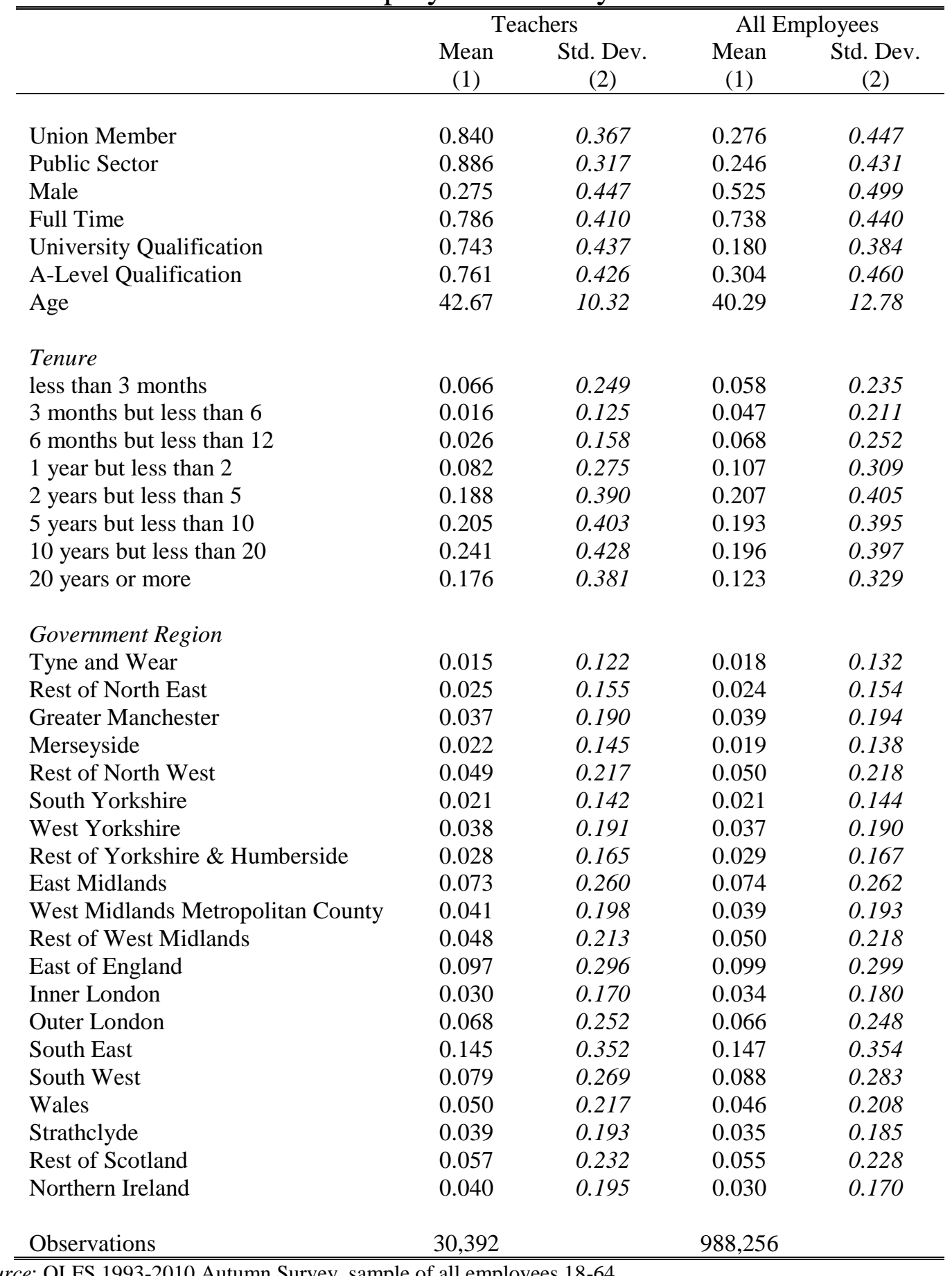

Source: QLFS 1993-2010 Autumn Survey, sample of all employees 18-64

Notes: Teachers defined as Standard Occupational Classification codes (1993-2000):233, 234, 235 and Standard Occupational Classification codes (2001-2010): 2314, 2315, 2316 
Table 4: Summary Statistics -News Coverage 1991-2010

\begin{tabular}{|c|c|c|c|c|c|c|c|c|c|}
\hline \multirow{2}{*}{\multicolumn{10}{|c|}{ Panel A: All Newspaper Stories }} \\
\hline & & & & & & & & & \\
\hline Relevance of Story & Allegations & Being Sued & Suing & $\begin{array}{c}\text { Being } \\
\text { Attacked }\end{array}$ & $\begin{array}{l}\text { Criminal } \\
\text { Activity }\end{array}$ & Sacked & $\begin{array}{c}\text { Employment } \\
\text { Tribunal }\end{array}$ & $\begin{array}{l}\text { Union } \\
\text { Activity }\end{array}$ & Total \\
\hline Extremely Relevant & 322 & 45 & 100 & 4 & 12 & 15 & 61 & 64 & 623 \\
\hline Highly Relevant & 179 & 28 & 52 & 45 & 53 & 36 & 43 & 112 & 548 \\
\hline Little Relevance & 155 & 12 & 3 & 19 & 123 & 14 & 12 & 56 & 394 \\
\hline Not Relevant & 55 & 1 & 2 & 10 & 68 & 4 & 0 & 4 & 144 \\
\hline Total & 711 & 86 & 157 & 78 & 256 & 69 & 116 & 236 & 1709 \\
\hline \multicolumn{10}{|c|}{ Panel B: Balanced Newspaper Panel Stories } \\
\hline Relevance of Story & Allegations & Being Sued & Suing & $\begin{array}{c}\text { Being } \\
\text { Attacked }\end{array}$ & $\begin{array}{l}\text { Criminal } \\
\text { Activity }\end{array}$ & Sacked & $\begin{array}{c}\text { Employment } \\
\text { Tribunal }\end{array}$ & $\begin{array}{c}\text { Union } \\
\text { Activity }\end{array}$ & Total \\
\hline Extremely Relevant & 222 & 27 & 78 & 3 & 6 & 9 & 48 & 48 & 441 \\
\hline Highly Relevant & 115 & 22 & 36 & 29 & 37 & 16 & 35 & 78 & 368 \\
\hline Little Relevance & 95 & 5 & 1 & 10 & 77 & 8 & 9 & 46 & 251 \\
\hline Not Relevant & 38 & 1 & 2 & 1 & 32 & 0 & 0 & 2 & 76 \\
\hline Total & 470 & 55 & 117 & 43 & 152 & 33 & 92 & 172 & 1136 \\
\hline
\end{tabular}

Source: LexisNexis 1991-2010. News search of national newspapers with the following term: headline(teacher) and court or damages or sued or jail or litigation or dismissed or fired or allegations and \#GC329\#. National Newspapers: Daily Mail, Daily Star, Mail on Sunday, Morning Star, The Express, Sunday Express, The Daily

Telegraph, Sunday Telegraph, The Sun, The News of the World, The Guardian, The Independent, The Observer, The People, The Times, The Sunday Times. The Balanced Panel of Newspaper Stories: Daily Mail, Mail on Sunday, The Guardian, The Independent, The Mirror, Daily Star, Observer, The Times, The Sunday Times 
Table 5: Total News Coverage by Story Subject

\begin{tabular}{|c|c|c|c|c|}
\hline \multicolumn{5}{|l|}{$\begin{array}{lcc}\text { Panel A: } & \text { All } & \text { Newspaper } \\
\text { Stories 1992-2010 } & \end{array}$} \\
\hline News Story Subject & $\begin{array}{l}\text { Story Type } \\
\text { Accusation }\end{array}$ & All Types & $\begin{array}{l}\text { Story Type } \\
\text { Accusation }\end{array}$ & All Types \\
\hline \multicolumn{5}{|l|}{ By School Type } \\
\hline Secondary School & $\begin{array}{c}435 \\
(68.1 \%)\end{array}$ & $\begin{array}{c}661 \\
(66.2 \%)\end{array}$ & $\begin{array}{c}706 \\
(67.0 \%)\end{array}$ & $\begin{array}{c}975 \\
(66.1 \%)\end{array}$ \\
\hline Primary School & $\begin{array}{c}126 \\
(19.7 \%)\end{array}$ & $\begin{array}{c}186 \\
(18.6 \%)\end{array}$ & $\begin{array}{c}184 \\
(17.5 \%)\end{array}$ & $\begin{array}{c}249 \\
(16.9 \%)\end{array}$ \\
\hline \multicolumn{5}{|l|}{ By Teacher Gender } \\
\hline Male Teacher & $\begin{array}{c}327 \\
(51.1 \%)\end{array}$ & $\begin{array}{c}469 \\
(46.9 \%)\end{array}$ & $\begin{array}{c}591 \\
(56.1 \%)\end{array}$ & $\begin{array}{c}762 \\
(51.6 \%)\end{array}$ \\
\hline Female Teacher & $\begin{array}{c}303 \\
(47.4 \%) \\
\end{array}$ & $\begin{array}{c}521 \\
(52.2 \%) \\
\end{array}$ & $\begin{array}{c}455 \\
(43.2 \%) \\
\end{array}$ & $\begin{array}{c}705 \\
(47.8 \%) \\
\end{array}$ \\
\hline All Stories & 639 & 999 & 1053 & 1476 \\
\hline \multicolumn{5}{|l|}{$\begin{array}{l}\text { Panel B: Balanced Newspaper } \\
\text { Panel Stories 1992-2010 }\end{array}$} \\
\hline News Story Subject & $\begin{array}{l}\text { Relevan } \\
\text { Story Type } \\
\text { Accusation }\end{array}$ & $\begin{array}{l}\text { Stories } \\
\text { All Types }\end{array}$ & $\begin{array}{l}\text { Any Releva } \\
\text { Story Type } \\
\text { Accusation }\end{array}$ & $\begin{array}{l}\text { Ice Stories } \\
\text { All Types }\end{array}$ \\
\hline By School Type & & & & \\
\hline Secondary School & $\begin{array}{c}285 \\
(66.3 \%)\end{array}$ & $\begin{array}{c}439 \\
(63.9 \%)\end{array}$ & $\begin{array}{c}443 \\
(65.0 \%)\end{array}$ & $\begin{array}{c}620 \\
(63.7 \%)\end{array}$ \\
\hline Primary School & $\begin{array}{c}90 \\
(20.9 \%)\end{array}$ & $\begin{array}{c}142 \\
(20.7 \%)\end{array}$ & $\begin{array}{c}128 \\
(18.8 \%)\end{array}$ & $\begin{array}{c}182 \\
(18.7 \%)\end{array}$ \\
\hline \multicolumn{5}{|l|}{ By Teacher Gender } \\
\hline Male Teacher & $\begin{array}{c}218 \\
(50.7 \%)\end{array}$ & $\begin{array}{c}315 \\
(45.9 \%)\end{array}$ & $\begin{array}{c}381 \\
(55.9 \%)\end{array}$ & $\begin{array}{c}490 \\
(50.4 \%)\end{array}$ \\
\hline Female Teacher & $\begin{array}{c}200 \\
(46.5 \%)\end{array}$ & $\begin{array}{c}362 \\
(52.7 \%)\end{array}$ & $\begin{array}{c}289 \\
(42.4 \%)\end{array}$ & $\begin{array}{c}471 \\
(48.4 \%)\end{array}$ \\
\hline All Stories & 430 & 687 & 677 & 973 \\
\hline \multicolumn{5}{|c|}{ Source: LexisNexis 1991-2010 of National Newspapers, Balanced Panel } \\
\hline \multicolumn{5}{|c|}{$\begin{array}{l}\text { Note: Percentages in parentheses represent proportion of all stories of that type on that subject. } \\
\text { Story Type: Accusation includes- Allegations, Being Sued and Criminal Activity. Union Activity } \\
\text { not included under All Types as is only counted in national totals as not based in one region or } \\
\text { reflect a specific teacher type. Total stories do not equal those from Table } 3 \text { as some stories are } \\
\text { double counted when both male and female teachers are mentioned, or both primary and secondary }\end{array}$} \\
\hline
\end{tabular}


Table 6: Union Membership on News Coverage

\begin{tabular}{lcccc}
\hline \hline \multicolumn{3}{l}{ Panel A: Extremely } & Relevant News Stories of Accusations & \\
P(Union Membership) & $(1)$ & $(2)$ & $(3)$ & $(4)$ \\
\hline Stories Regionally & $0.548^{* *}$ & $0.588^{* * *}$ & $0.674^{* *}$ & $0.498^{* *}$ \\
& 0.235 & 0.206 & 0.325 & 0.251 \\
Stories Regionally & -0.024 & $-0.034^{* *}$ & $-0.047^{* *}$ & $-0.046^{* * *}$ \\
Squared & 0.018 & 0.015 & 0.019 & 0.014 \\
& & & & \\
\hline Marginal Effect at & $0.512^{* *}$ & $0.535^{* * *}$ & $0.603^{*}$ & $0.428^{*}$ \\
Mean & 0.234 & 0.207 & 0.326 & 0.252 \\
\hline
\end{tabular}

Panel B: All Relevant News Stories of Accusations

\begin{tabular}{lcccc} 
P(Union Membership) & $(1)$ & $(2)$ & $(3)$ & $(4)$ \\
\hline Stories Regionally & $0.841 * * *$ & $0.783 * * *$ & $0.758^{* * *}$ & $0.449 * * *$ \\
& 0.158 & 0.139 & 0.200 & 0.149 \\
Stories Regionally & $-0.041^{* * *}$ & $-0.039 * * *$ & $-0.034 * * *$ & $-0.026 * * *$ \\
Squared & 0.008 & 0.007 & 0.008 & 0.007 \\
& & & & \\
\hline Marginal Effect at & $0.731 * * *$ & $0.679 * * *$ & $0.667 * * *$ & $0.380 * *$ \\
Mean & 0.160 & 0.140 & 0.201 & 0.150 \\
\hline
\end{tabular}

Panel C: Little/No Relevance News Stories of Accusations

\begin{tabular}{lcccc} 
P(Union Membership) & $(1)$ & $(2)$ & $(3)$ & $(4)$ \\
\hline Stories Regionally & 0.098 & 0.169 & 0.222 & -0.152 \\
& 0.202 & 0.177 & 0.153 & 0.146 \\
Stories Regionally & 0.015 & 0.003 & -0.004 & 0.004 \\
Squared & 0.012 & 0.010 & 0.005 & 0.005 \\
& & & & \\
\hline Marginal Effect at & 0.120 & 0.173 & 0.216 & -0.145 \\
Mean & 0.202 & 0.177 & 0.153 & 0.146 \\
\hline & & & & \\
Teacher Characteristics & & & $\checkmark$ & $\checkmark$ \\
Regional Effects & & & & $\checkmark$ \\
Year Effects & 30,392 & 30,392 & 30,392 & 30,392 \\
\hline Observations & & & &
\end{tabular}

Source: QLFS 1993-2010

Notes: Estimates from a logit regression of individual decision to join a union. Reporting the marginal effects after transforming by $P(\widehat{\text { Unıo }}) *(1-P(\widehat{\text { Unıon }}))$. All coefficients and standard errors are multiplied by 100 for ease of interpretation. Estimates can be read a percentage change in probability. Marginal effect at mean calculated by $\beta_{1}+2 \beta_{2} \overline{S_{J t}}$. Accusation stories are stories involving Allegations, Being Sued and Criminal Activity. Stories Regionally is a count for the number of news stories that originated in the region that the teacher resides. Standard errors in italics, clustered at the regional level. 
Table 7: Union Membership on Regional and National News Coverage of Accusations

\begin{tabular}{lccc}
\hline \hline & $\begin{array}{c}\text { Extremely } \\
\text { Relevant } \\
\text { Stories }\end{array}$ & $\begin{array}{c}\text { Story Relevance } \\
\text { Relevant } \\
\text { Stories }\end{array}$ & $\begin{array}{c}\text { Little/No } \\
\text { Relevance }\end{array}$ \\
P(Union Membership) & $0.481^{*}$ & $0.436^{* * *}$ & -0.159 \\
\hline Stories Regionally & 0.263 & 0.147 & 0.137 \\
Stories Regionally & $-0.042^{* * *}$ & $-0.022^{* * *}$ & 0.005 \\
Squared & 0.015 & 0.001 & 0.004 \\
Stories Nationally & $0.108^{* *}$ & 0.030 & -0.205 \\
Stories Nationally & 0.050 & 0.043 & 0.236 \\
Squared & $-0.002^{*}$ & 0.000 & 0.005 \\
& 0.001 & 0.001 & 0.001 \\
\hline Marginal Effect at & $0.469^{*}$ & $0.403^{* *}$ & -0.182 \\
Mean & 0.270 & 0.158 & 0.160 \\
Total Effect at Mean & 1.460 & 1.205 & -2.003 \\
\hline Teacher Characteristics & $\checkmark$ & $\checkmark$ & $\checkmark$ \\
Regional Effects & $\checkmark$ & $\checkmark$ & $\checkmark$ \\
Time Trend & $\checkmark$ & 30,392 & 30,392 \\
\hline Observations & 30,392 & & $\checkmark$ \\
\hline \hline
\end{tabular}

Source: QLFS 1993-2010 Notes: Estimates from a logit regression of individual decision to join a union on news stories. Reporting the marginal effects. All coefficients and standard errors are multiplied by 100 for ease of interpretation. Estimates can be read a percentage change in probability. Marginal effect at mean calculated by $\beta_{1}+2 \beta_{2} \overline{s_{J}}$. Total effect at mean $\left(\overline{s_{J}} \beta+\overline{s_{J}^{2}} \beta+\bar{s} \beta+\overline{s^{2}} \beta\right)$. Accusation stories are stories involving Allegations, Being Sued and Criminal Activity. Stories Regionally is a count for the number of news stories that originated in the region that the teacher resides in the previous 12 months. Stories Nationally is a count for the number of all news stories in the previous 12 months, including stories that could not be allocated to a specific region. Standard errors in italics, clustered at the regional level. 
Table 8: Union Membership on Union Membership by Teacher and Story School Type

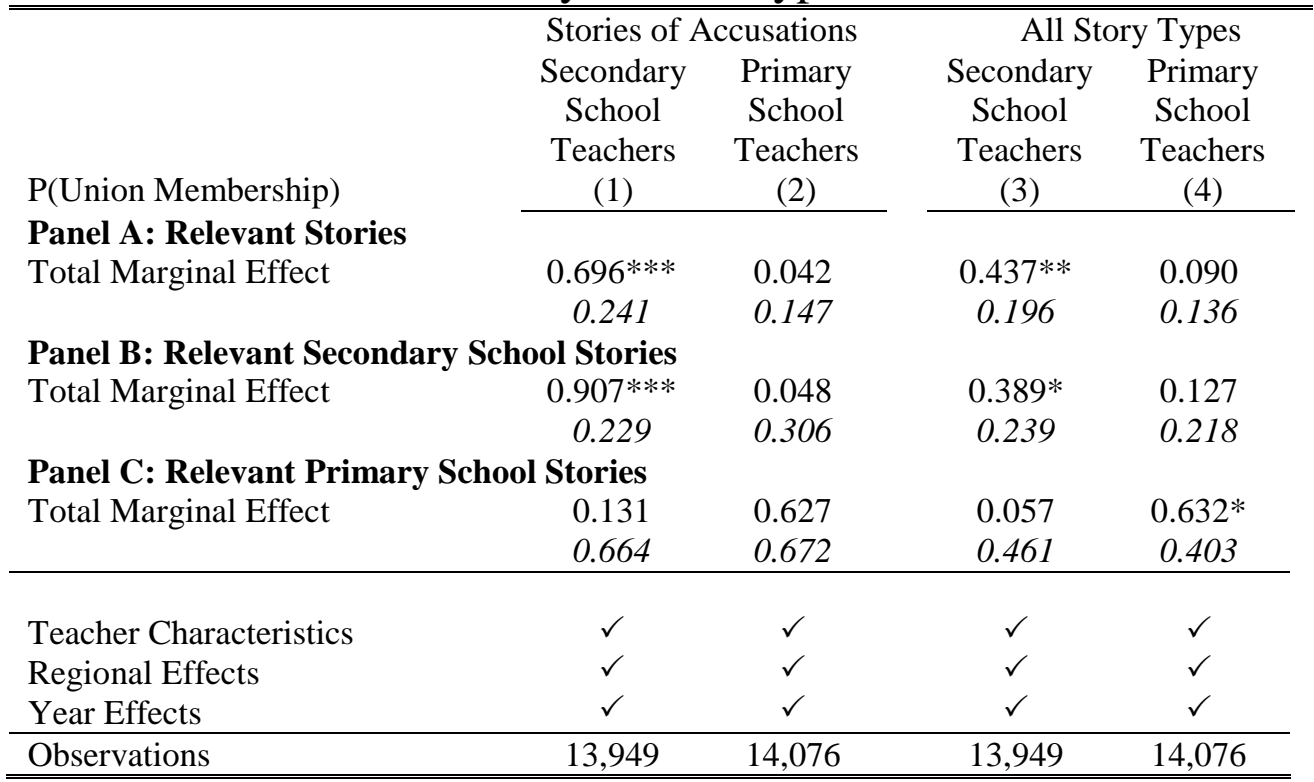

Source: QLFS 1993-2010 Notes: Estimates from a logit regression of individual decision to join a union on news stories. Reporting the marginal effects at mean after accounting for quadratic terms. All coefficients and standard errors are multiplied by 100 for ease of interpretation. Estimates can be read a percentage change in probability. Marginal effect at mean calculated by $\beta_{1}+2 \beta_{2} \overline{S_{J}}$. All estimates conditional on teacher characteristics Accusation stories are stories involving Allegations, Being Sued and Criminal Activity. Relevant Stories include both Extremely and Highly relevant news stories. Stories Regionally is a count for the number of news stories that originated in the region that the teacher resides in the previous 12 months. Standard errors in italics, clustered at the regional level.

Table 9: Union Membership on Union Membership by Teacher and Story Gender

\begin{tabular}{|c|c|c|c|c|}
\hline \multirow[b]{4}{*}{ P(Union Membership) } & \multicolumn{2}{|c|}{ Stories of Accusations } & \multicolumn{2}{|c|}{ All Story Types } \\
\hline & Male & Female & Male & Female \\
\hline & Teachers & Teachers & Teachers & Teachers \\
\hline & $(1)$ & & & \\
\hline \multicolumn{5}{|c|}{ Panel A: Relevant Stories } \\
\hline \multirow[t]{2}{*}{ Total Marginal Effect } & 0.038 & $0.51 * *$ & 0.147 & 0.294 \\
\hline & 0.154 & 0.201 & 0.18 & 0.136 \\
\hline \multicolumn{5}{|c|}{ Panel B: Relevant Male Teacher Stories } \\
\hline \multirow[t]{2}{*}{ Total Marginal Effect } & $0.591 *$ & $0.897 * *$ & $0.564 *$ & $0.473^{*}$ \\
\hline & 0.305 & 0.374 & 0.428 & 0.363 \\
\hline \multicolumn{5}{|c|}{ Panel C: Relevant Female Teacher Stories } \\
\hline \multirow[t]{2}{*}{ Total Marginal Effect } & -0.055 & 0.386 & 0.086 & 0.128 \\
\hline & 0.305 & 0.412 & 0.220 & 0.221 \\
\hline Teacher Characteristics & $\checkmark$ & $\checkmark$ & $\checkmark$ & $\checkmark$ \\
\hline Regional Effects & $\checkmark$ & $\checkmark$ & $\checkmark$ & $\checkmark$ \\
\hline Year Effects & $\checkmark$ & $\checkmark$ & $\checkmark$ & $\checkmark$ \\
\hline Observations & 8,361 & 22,031 & 8,361 & 22,031 \\
\hline
\end{tabular}




\section{Table 10: Union Membership on Union Membership by Occupation}

\begin{tabular}{|c|c|c|c|c|c|}
\hline Occupation Group & Teachers & $\begin{array}{c}\text { Education } \\
\text { Assistants } \\
\text { (2) }\end{array}$ & $\begin{array}{c}\text { Higher } \\
\text { Education } \\
(3)\end{array}$ & $\begin{array}{c}\text { Non Teacher } \\
\text { Public Sector } \\
\text { Graduates } \\
\text { (4) }\end{array}$ & $\begin{array}{c}\text { Non Teacher } \\
\text { Graduates } \\
\text { (5) }\end{array}$ \\
\hline Relevant Stories & $0.498 * *$ & 0.688 & 0.235 & 0.161 & 0.052 \\
\hline Regionally & 0.251 & 0.577 & 0.422 & 0.202 & 0.090 \\
\hline Relevant Stories & $-0.046 * * *$ & -0.021 & -0.018 & -0.001 & -0.000 \\
\hline Regionally Squared & 0.014 & 0.023 & 0.018 & 0.010 & 0.005 \\
\hline Marginal Effect at & $0.428 *$ & 0.622 & 0.185 & 0.133 & 0.051 \\
\hline Mean & 0.252 & 0.582 & 0.425 & 0.204 & 0.091 \\
\hline Teacher Characteristics & $\checkmark$ & $\checkmark$ & $\checkmark$ & $\checkmark$ & $\checkmark$ \\
\hline Regional Effects & $\checkmark$ & $\checkmark$ & $\checkmark$ & $\checkmark$ & $\checkmark$ \\
\hline Year Effects & $\checkmark$ & $\checkmark$ & $\checkmark$ & $\checkmark$ & $\checkmark$ \\
\hline Observations & 30,392 & 10,022 & 9,007 & 49,671 & 154,932 \\
\hline
\end{tabular}

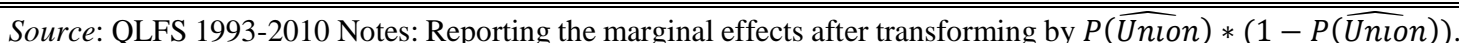
All coefficients and standard errors are multiplied by 100 for ease of interpretation. Estimates can be read a percentage change in probability. Marginal effect at mean calculated by $\beta_{1}+2 \beta_{2} \overline{S_{J}}$. Accusation stories are stories involving Allegations, Being Sued and Criminal Activity. Relevant Stories include both Extremely and Highly relevant news stories. Stories Regionally is a count for the number of news stories that originated in the region that the teacher resides in the previous 12 months. SOC codes: Educational Assistants 652, 6124; Higher Education 230, 231, 2311, 2312. Standard errors in italics, clustered at the regional level. 
Table 11: Union Membership on Union Membership by News Lag Period

\begin{tabular}{|c|c|c|}
\hline $\begin{array}{c}\text { News Lag period } \\
\text { P(Union Membership) }\end{array}$ & $\begin{array}{c}\text { Marginal Effects } \\
(1)\end{array}$ & $\begin{array}{c}\text { Total Marginal } \\
\text { Effect } \\
(2)\end{array}$ \\
\hline Stories Last 6 Months & $\begin{array}{c}0.487 * * \\
0.214\end{array}$ & $\begin{array}{c}0.424 * * \\
0.215\end{array}$ \\
\hline $\begin{array}{l}\text { Stories Last } 6 \text { Months } \\
\text { Squared }\end{array}$ & $\begin{array}{c}-0.053 * * * \\
0.019\end{array}$ & \\
\hline $\begin{array}{l}\text { Stories 7-12 Months } \\
\text { Previous } \\
\text { Stories 7-12 Months } \\
\text { Previous Squared }\end{array}$ & $\begin{array}{c}0.508 * * * \\
0.148 \\
-0.037 * * * \\
0.008\end{array}$ & $\begin{array}{c}0.453^{* * * *} \\
0.148\end{array}$ \\
\hline $\begin{array}{l}\text { Stories 13-18 Months } \\
\text { Previous } \\
\text { Stories 13-18 Months } \\
\text { Previous Squared }\end{array}$ & $\begin{array}{c}0.948 * * * \\
0.348 \\
-0.078 * * * \\
0.030\end{array}$ & $\begin{array}{c}0.861 * * \\
0.349\end{array}$ \\
\hline $\begin{array}{l}\text { Stories 19-24 Months } \\
\text { Previous } \\
\text { Stories 19-24 Months } \\
\text { Previous Squared }\end{array}$ & $\begin{array}{l}-0.182 \\
0.217 \\
0.010 \\
0.013\end{array}$ & $\begin{array}{c}-0.166 \\
0.218\end{array}$ \\
\hline $\begin{array}{l}\text { Stories 25-30 Months } \\
\text { Previous } \\
\text { Stories 25-30 Months } \\
\text { Previous Squared }\end{array}$ & $\begin{array}{l}-0.319 \\
0.326 \\
0.035 \\
0.032\end{array}$ & $\begin{array}{c}-0.280 \\
0.328\end{array}$ \\
\hline $\begin{array}{l}\text { Stories 31-36 Months } \\
\text { Previous } \\
\text { Stories 25-30 Months } \\
\text { Previous Squared }\end{array}$ & $\begin{array}{l}-0.385 \\
0.296 \\
0.015\end{array}$ & $\begin{array}{c}-0.348 \\
0.296\end{array}$ \\
\hline $\begin{array}{l}\text { Teacher Characteristics } \\
\text { Regional Effects } \\
\text { Year Effects }\end{array}$ & $\begin{array}{l}\checkmark \\
\checkmark \\
\checkmark\end{array}$ & $\begin{array}{l}\checkmark \\
\checkmark \\
\checkmark\end{array}$ \\
\hline Obs & 30,392 & 30,392 \\
\hline
\end{tabular}

Source: QLFS 1993-2010 Notes: Estimates from a logit regression. Reporting the marginal effects All coefficients and standard errors are multiplied by 100 for ease of interpretation. Accusation stories are stories involving Allegations, Being Sued and Criminal Activity. Relevant Stories include both Extremely and Highly relevant news stories. Standard errors in italics, clustered at the regional level. 
Figure 1: Union Density Time Series by Occupation

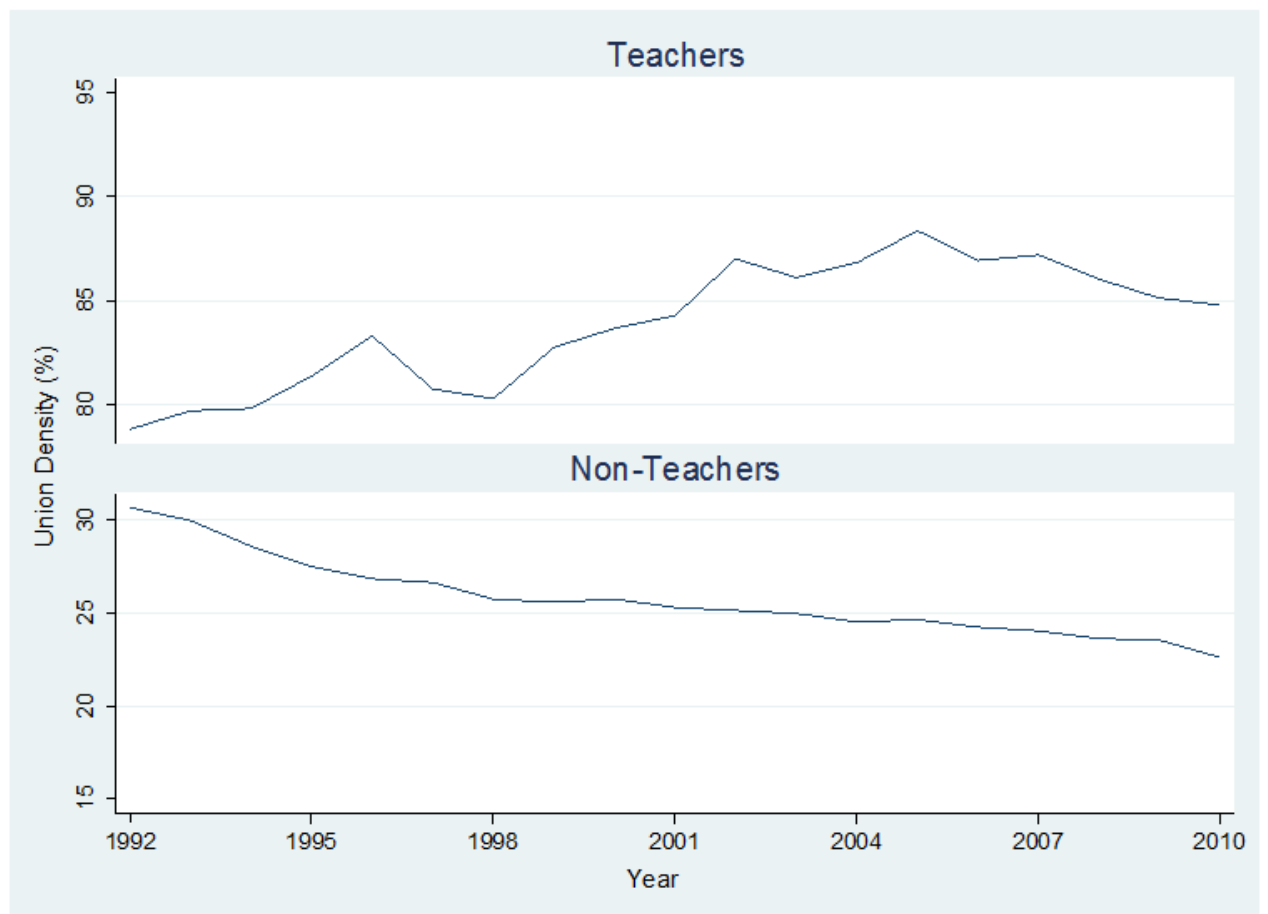

Source: QLFS 1992-2010. Proportion of all adults reporting an occupation who are union members. Teachers defined by occupational codes 2314, 2315, 2316

\section{Figure 2: Teacher Perception of Union Power}

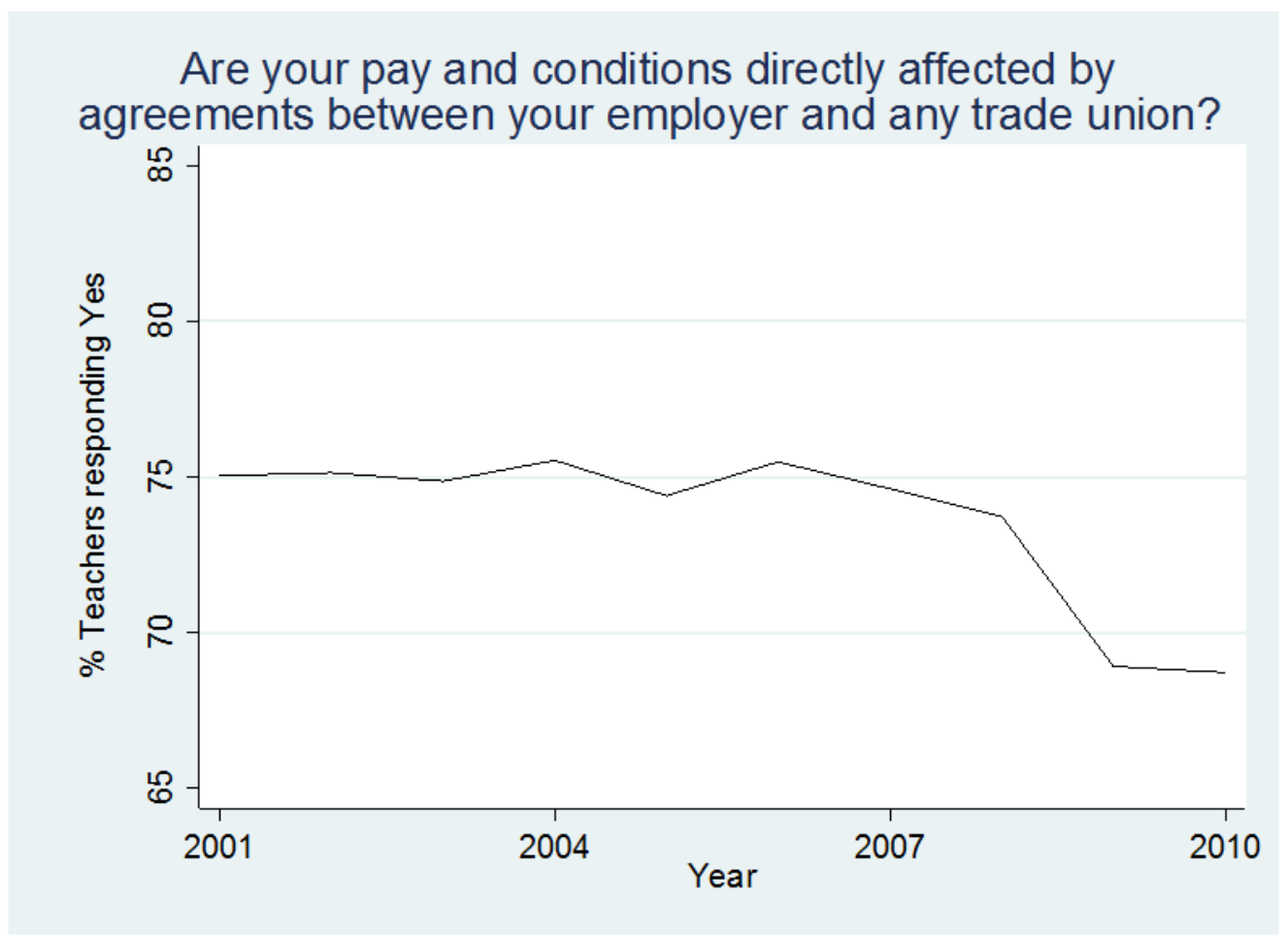

Source: QLFS 2001-2010: Teachers defined by occupational codes 2314, 2315, 2316. All teachers, regardless of union status were ask "Are your pay and conditions directly affected by agreements between your employer and any trade union? 
Figure 3: Illustration of Union Membership Decision

Panel A: Utility curve of teacher $U\left(Y, \theta^{*}\right)$ with wages $w$, union dues $c$.

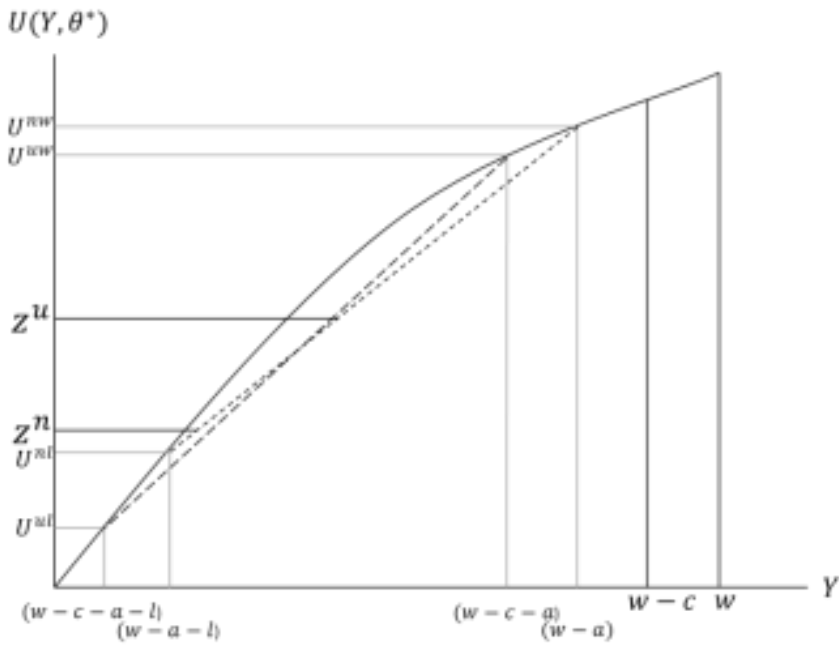

Notes: $U^{u w}\left(U^{u l}\right)$ is the utility of a union member who has had an allegation made against them and won (lost) their case. Similarly for non-members $U^{n w}\left(U^{n l}\right)$. $Z^{u}\left(Z^{n}\right)$ represents the expected utility once an allegation has been made for a (non) union member. $a$ represents the cost of an allegation and $l$ the additional cost of being found guilty.

- - - Union Member

---.- Non Union Member

Panel B: Expected utilities of teacher $U\left(Y, \theta^{*}\right)$ with a high perceived risk $\delta(s)=0.5$ $U\left(Y, \theta^{*}\right)$

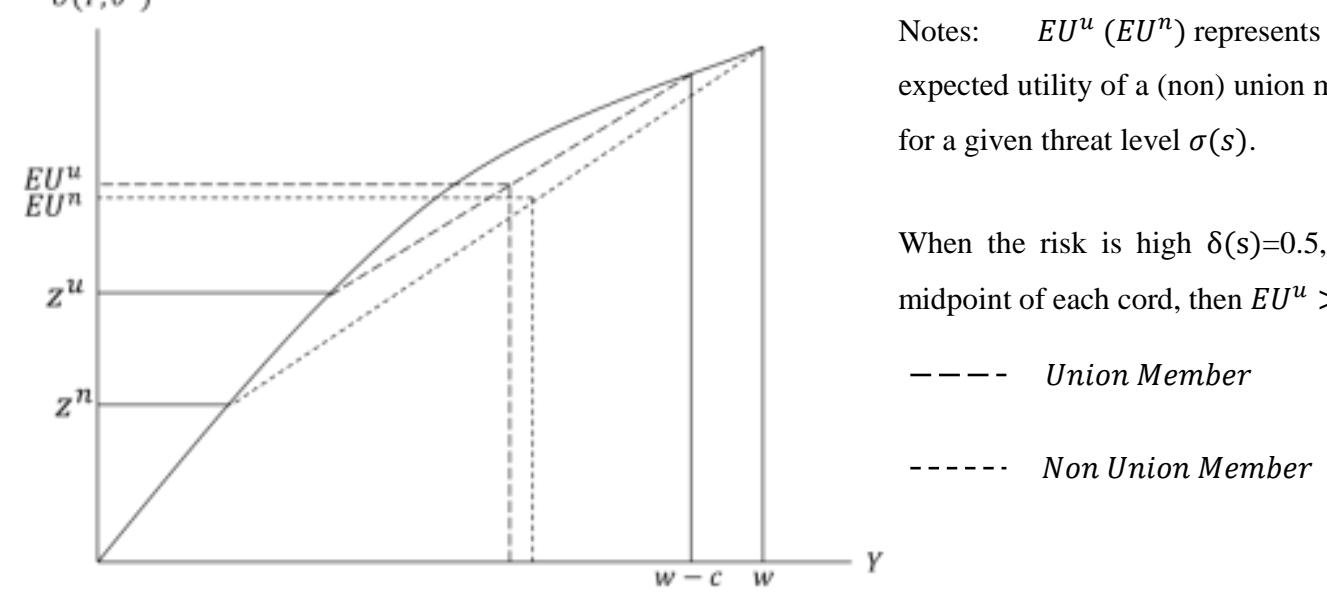

Panel C: Expected utilities of teacher $U\left(Y, \theta^{*}\right)$ with a low perceived risk $\delta(s)=0.1$

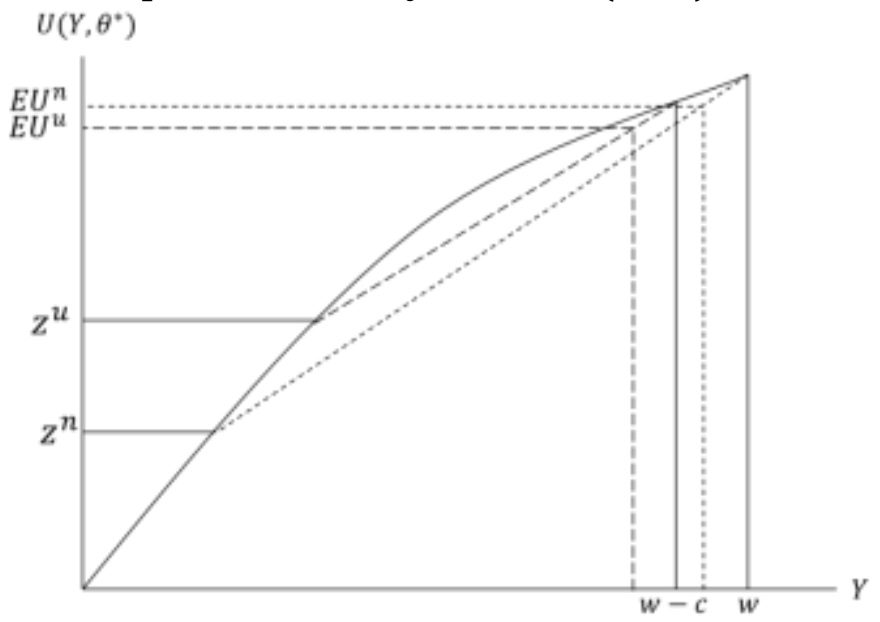

Notes: $\quad E U^{u}\left(E U^{n}\right)$ represents the expected utility of a (non) union member for a given threat level $\sigma(s)$.

When the risk is low $\delta(s)=0.1$, teachers are at a higher point on each cord and then $E U^{u}>E U^{n}$.

- - - Union Member

-.-.. Non Union Member 
Figure 4 Union Density and Relevant News Stories over time

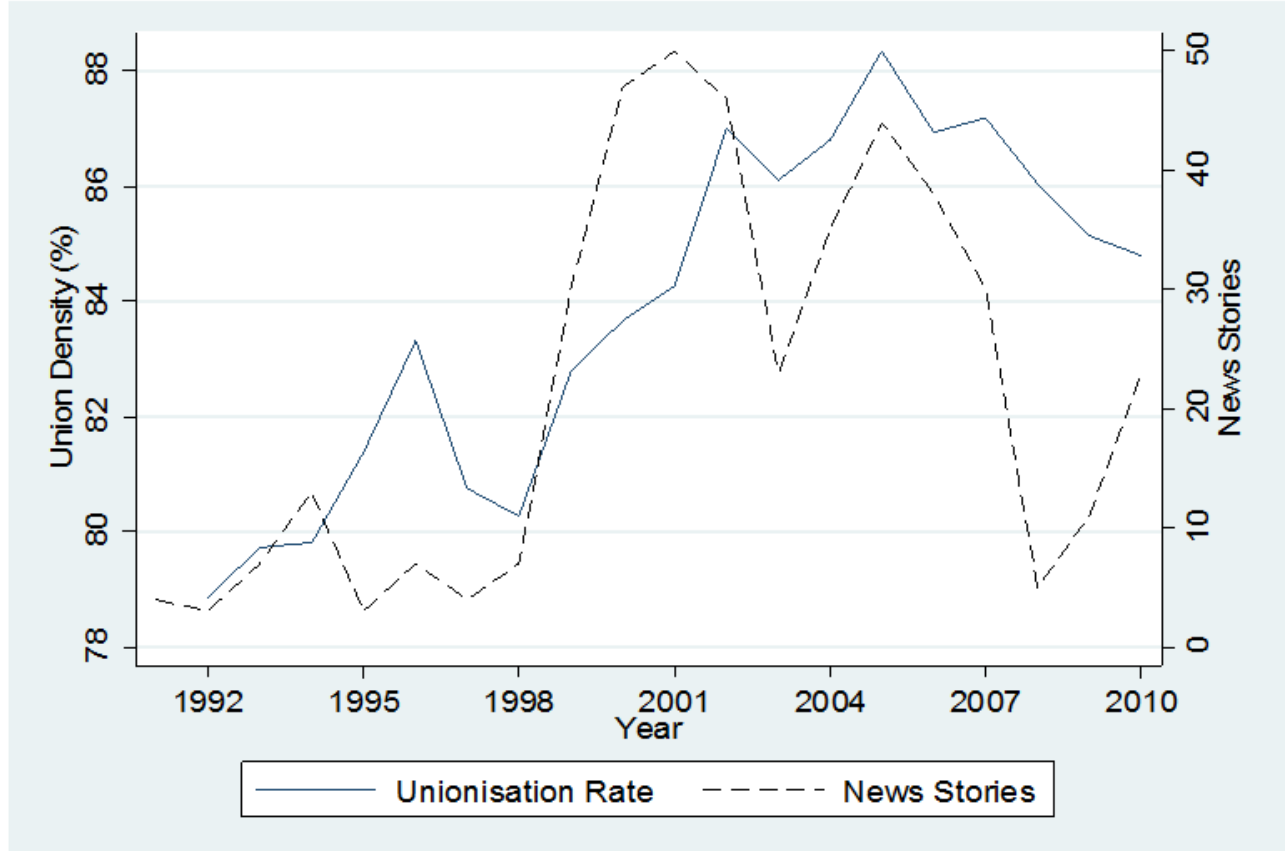

Source: QLFS 1992:2010, Lexis Nexus 1992-2010 Notes: Annual union density based on mean union membership of teachers based on QLFS reporting year. News story total based on total relevant news stories about teachers concerning Allegations; Being Sued, and Criminal Activity over a calendar year.

\section{Figure 5 Event Study of Union Membership and Media Coverage}

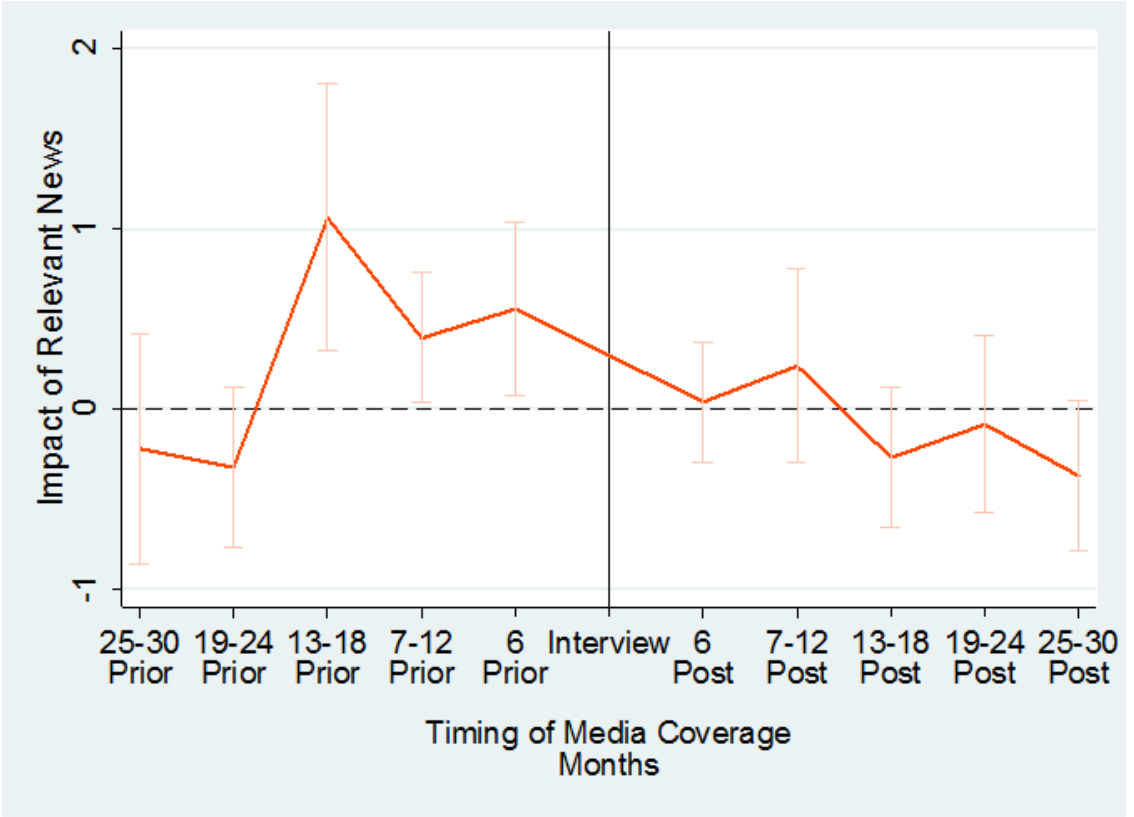

Source: QLFS 1993-2010 Notes: Predictions of probability union from a logit regression for each year. Allow separate effect of news stories regionally (and their square), for each six month period up to thirty months post or prior to the interview. 


\section{Figure 6 Predicted Union Density with and without Media Reports}

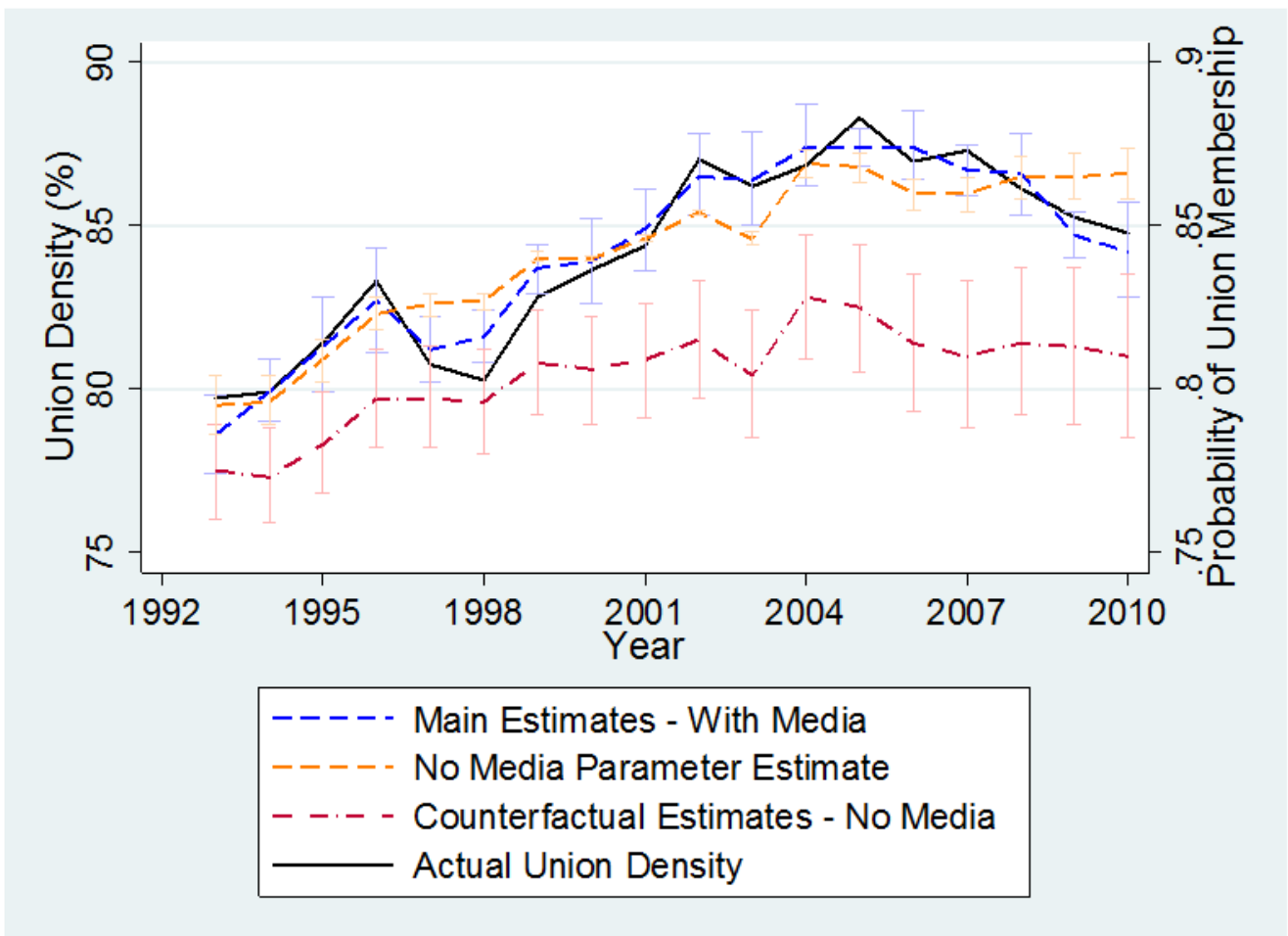

Source: QLFS 1993-2010 Notes: Predictions of probability union from a logit regression for each year. Allow separate effect of news stories regionally and nationally (and their square), for each six month period up to thirty six months prior to the interview. The counterfactual estimates generated with the same parameters apart from setting the media terms to zero. Accusation stories are stories involving Allegations, Being Sued and Criminal Activity. Stories Regionally is a count for the number of news stories that originated in the region that the teacher resides in the previous 6 months, 7-12 months, 13-18 months, 19-24 months, 25-30 months, 31-36months. Similarly Stories Nationally is a count for the number of all news stories, including stories that could not be allocated to a specific region. Standard errors in italics, clustered at the regional level. 


\section{Appendix 1: Local Authorities who responded to the Freedom of information request regarding allegations}

All Local Authorities who responded (Years of data):

Local Authority (Years), Barnet (2) Barnsley (3), Bath and North East Somerset (3), Bedford (1), Bexley (2), Blackburn with Darwen (3), Bolton (3), Bracknell Forest (2), Bradford (3), Brent (4), Bristol City (3), Bromley (3), Buckinghamshire (4), Calderdale (3), Cambridge (2), Camden (3), Central Bedfordshire (1), Cheshire East Council (1), Cheshire West and Chester (2), Cornwall (1), Croyden (3), Cumbria (3), Derby (1), Derbyshire (3), Devon (1), Doncaster (3), Dorset (3), Dudley (3), Durham (3), East Riding of Yorkshire (4), East Sussex (2), Essex (4), Gateshead (3), Gloustershire (2), Greenwich (4), Hackney (1), Hammersmith and Fulham (2), Hampshire (3), Haringey (2), Havering (4), Hertfordshire (2), Hillingdon (3), Hounslow (2), Isle of Scilly (4), Isle of Wight (3), Islington (4), Kensington and Chelsea (2), Kent (4), Kingston Upon Hull (3), Kingston Upon Thames (4), Kirklees (3), Knowsley (3), Lancashire (4), Leeds (4), Leicester (3), Lewisham (4), Lincolnshire (1), Liverpool (1), Luton (2), Manchester (2), Medway (3), Milton Keyenes (1), Newham (1), Norfolk (3), North East Lincolnshire (3), North Lincolnshire (1), North Somerset (4), North Yorkshire (3), Northumberland (4), Nottingham City (4), Nottingham County (2), Oldham (4), Oxfordshire (4), Peterborough (1), Plymouth (4), Poole (3), Reading (4), Redbridge (3), Richmond (1), Rochdale (3), Rotherham (1), Rutland (4), Salford (4), Sandwell (3), Scilly Isles (4), Sheffield (2), Shropshire (1), Slough (2), Solihull (4), Somerset (4), South Glouster (2), Southampton (2), Southend (3), St Helens (4), Stockport (4), Suffolk (3), Surrey (2), Sutton (2), Swindon (2), Telford and Wrekin (2), Thurrock (4), Torbay (3), Trafford (2), Wakefield (3), Walsall (4), Waltham Forest (3), Wandsworth (4), Warrington (2), West Berkshire (2), West Sussex (3), Wigan (2), Wiltshire (2), Winsor and Maidenhead (2), Wirral (4), Wokingham (2), Wolverhampton (2), Worcestershire (4), York (3), All (323)

Balanced Panel of Local Authorities 2008-2010:

Barnsley, Bath and North East Somerset, Blackburn with Darwen, Bolton, Bradford, Brent, Bristol City, Bromley, Buckinghamshire, Calderdale, Camden, Croydon, Cumbria, Derbyshire, Doncaster, Dorset, Dudley, Durham, East Riding of Yorkshire, Essex, Greenwich, Hampshire, Havering, Hillingdon, Isle of Scilly, Isle of Wight, Islington, Kent, Kingston Upon Hull, Kingston Upon Thames, Kirklees, Lancashire, Leeds, Leicester, Lewisham, Medway, North East Lincolnshire, North Somerset, North Yorkshire, Northumberland, Nottingham City, Oldham, Oxfordshire, Plymouth, Poole, Reading, Redbridge, Rutland, Salford, Sandwell, Sicily Isles, Solihull, Somerset, Southend, St Helens, Stockport, Suffolk, Thurrock, Torbay, Wakefield, Walsall, Waltham forest, Wandsworth, West Sussex, Wirral, Worcestershire 


\section{Appendix Tables}

\begin{tabular}{lc} 
Appendix Table 1: Reasons for Union Membership \\
\hline "What were the MAIN reasons why you initially joined a teacher \\
union?" \\
Belief in the union movement & $40 \%$ \\
To improve job security & $44 \%$ \\
To improve terms and conditions & $56 \%$ \\
For solidarity with other workers & $24 \%$ \\
Advice/opinion on educational policy & $62 \%$ \\
Support in the event of allegations from pupils & $85 \%$ \\
No particular reason & $3 \%$ \\
Observations & 176 \\
\hline \hline
\end{tabular}

Source: Online Survey of Hertfordshire Teachers 2010/11 for unrelated evaluation of UK Resilience Programme on teaching staff (Murphy 2011) 
Appendix Table 2: Media Rubric

\begin{tabular}{|c|c|c|c|c|c|c|c|c|c|}
\hline & Allegations & $\begin{array}{l}\text { Being } \\
\text { Sued }\end{array}$ & Suing & $\begin{array}{c}\text { Being } \\
\text { Attacked }\end{array}$ & $\begin{array}{l}\text { Criminal } \\
\text { Activity }\end{array}$ & Sacked & $\begin{array}{c}\text { Employment } \\
\text { Tribunal }\end{array}$ & $\begin{array}{c}\text { Union } \\
\text { Activity }\end{array}$ & Total \\
\hline
\end{tabular}

\begin{tabular}{|c|c|c|c|c|c|c|c|c|c|}
\hline Stories & 322 & 45 & 100 & 4 & 12 & 15 & 61 & 64 & 623 \\
\hline $\begin{array}{l}\text { Highly } \\
\text { Relevant }\end{array}$ & $\begin{array}{l}\text { Currently } \\
\text { on trial, no } \\
\text { verdict }\end{array}$ & $\begin{array}{l}\text { May be } \\
\text { sued, } \\
\text { could be } \\
\text { sued }\end{array}$ & $\begin{array}{l}\text { Lose } \\
\text { case, } \\
\text { indirectly } \\
\text { related to } \\
\text { school }\end{array}$ & $\begin{array}{l}\text { Parent- } \\
\text { Pupil } \\
\text { attacks } \\
\text { teacher } \\
\text { outside of } \\
\text { school }\end{array}$ & $\begin{array}{l}\text { Criminal } \\
\text { accusations } \\
\text { from pupil }\end{array}$ & $\begin{array}{l}\text { Inappropriate } \\
\text { behaviour, not } \\
\text { up to } \\
\text { standards }\end{array}$ & $\begin{array}{l}\text { Other Unfair } \\
\text { dismissal, } \\
\text { inappropriate } \\
\text { behaviour }\end{array}$ & $\begin{array}{l}\text { As above } \\
\text { but brief } \\
\text { mention or } \\
\text { union } \\
\text { demands }\end{array}$ & \\
\hline Stories & 179 & 28 & 52 & 45 & 53 & 36 & 43 & 112 & 548 \\
\hline $\begin{array}{l}\text { Little } \\
\text { Relevance }\end{array}$ & $\begin{array}{l}\text { Guilty of } \\
\text { lesser } \\
\text { offence, on } \\
\text { trial of hard } \\
\text { offence }\end{array}$ & $\begin{array}{l}\text { School/ } \\
\text { Council } \\
\text { sued }\end{array}$ & $\begin{array}{l}\text { Threats to } \\
\text { sue for } \\
\text { indirect } \\
\text { teaching }\end{array}$ & $\begin{array}{l}\text { Attacked } \\
\text { by ex } \\
\text { pupil }\end{array}$ & $\begin{array}{l}\text { School } \\
\text { related crime }\end{array}$ & $\begin{array}{l}\text { Miscellaneous } \\
\text { school related } \\
\text { activity }\end{array}$ & $\begin{array}{l}\text { Union back } \\
\text { the dismal }\end{array}$ & $\begin{array}{l}\text { Comment } \\
\text { on } \\
\text { education } \\
\text { policy }\end{array}$ & \\
\hline Stories & 155 & 12 & 3 & 19 & 123 & 14 & 12 & 56 & 394 \\
\hline $\begin{array}{l}\text { No } \\
\text { Relevance }\end{array}$ & $\begin{array}{l}\text { Admits } \\
\text { guilt of } \\
\text { extreme } \\
\text { sexual } \\
\text { abuse }\end{array}$ & $\begin{array}{l}\text { Non } \\
\text { school } \\
\text { related } \\
\text { activity }\end{array}$ & $\begin{array}{l}\text { Non } \\
\text { school } \\
\text { related } \\
\text { activity }\end{array}$ & $\begin{array}{l}\text { Non } \\
\text { school } \\
\text { related } \\
\text { activity }\end{array}$ & $\begin{array}{l}\text { Child } \\
\text { pornography } \\
\text { /murder }\end{array}$ & $\begin{array}{l}\text { Non-school } \\
\text { related } \\
\text { activity }\end{array}$ & $\begin{array}{l}\text { Non-school } \\
\text { related } \\
\text { activity }\end{array}$ & $\begin{array}{l}\text { Anti-union } \\
\text { members }\end{array}$ & \\
\hline Stories & 55 & 1 & 2 & 10 & 68 & 4 & 0 & 4 & 144 \\
\hline Total & 711 & 86 & 157 & 78 & 256 & 69 & 116 & 236 & 1709 \\
\hline
\end{tabular}




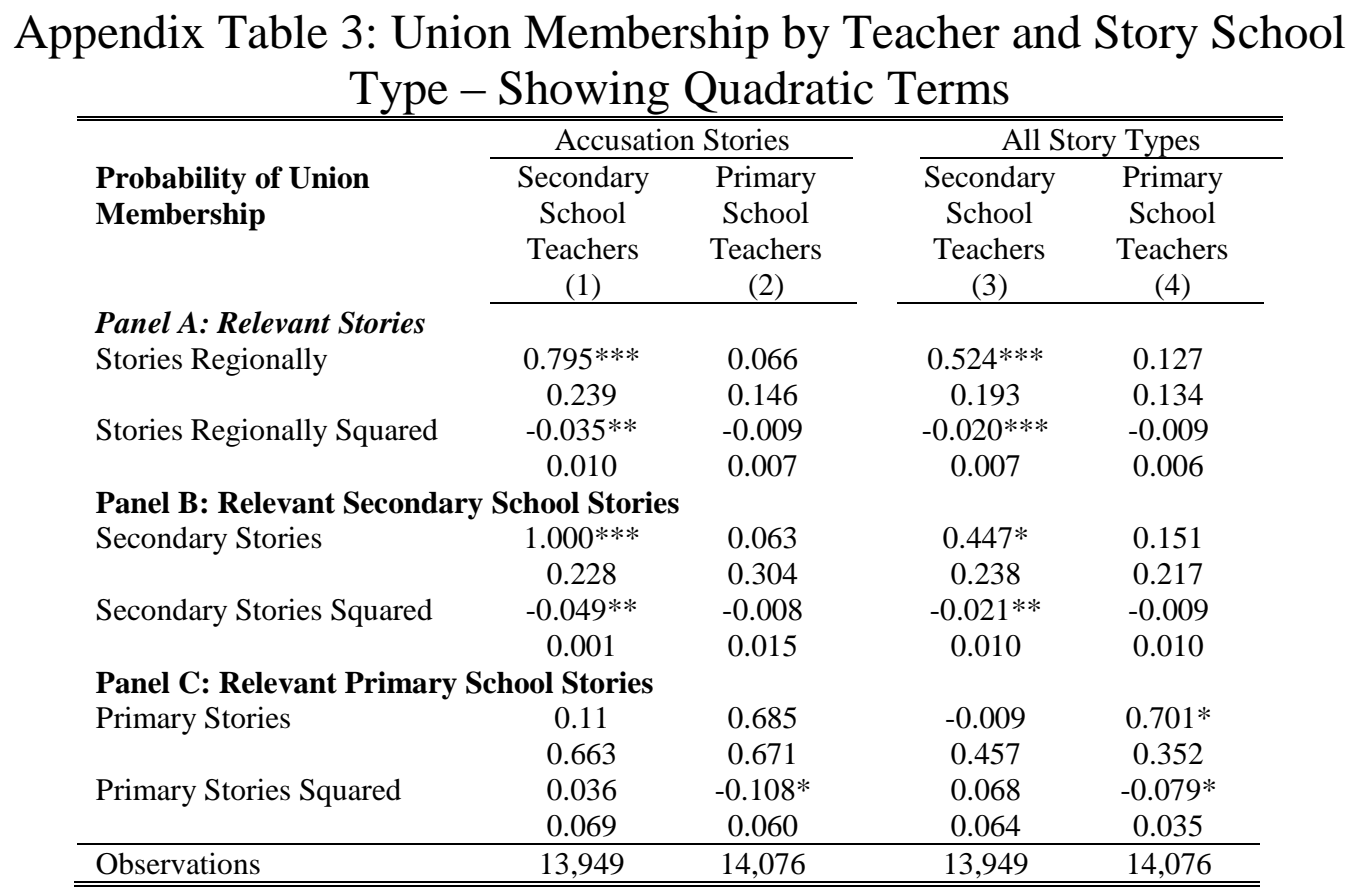

Source: QLFS 1993-2010 Notes: Estimates from a logit regression of individual decision to join a union on news stories. Reporting the marginal effects at mean. All coefficients and standard errors are multiplied by 100 for ease of interpretation. Estimates can be read a percentage change in probability. All estimates conditional on teacher characteristics Accusation stories are stories involving Allegations, Being Sued and Criminal Activity. Relevant Stories include both Extremely and Highly relevant news stories. Stories Regionally is a count for the number of news stories that originated in the region that the teacher resides in the previous 12 months. Standard errors in italics, clustered at the regional level.

\section{Appendix Table 4: Union Membership by Teacher and Story School} Type - Showing Quadratic Terms

\begin{tabular}{|c|c|c|c|c|}
\hline \multirow{3}{*}{$\begin{array}{l}\text { Probability of Union } \\
\text { Membership }\end{array}$} & \multicolumn{2}{|c|}{ Accusation Stories } & \multicolumn{2}{|c|}{ All Story Types } \\
\hline & Male & Female & Male & Female \\
\hline & $\begin{array}{c}\text { Teachers } \\
(1)\end{array}$ & $\begin{array}{c}\text { Teachers } \\
(2)\end{array}$ & $\begin{array}{c}\text { Teachers } \\
(3)\end{array}$ & $\begin{array}{c}\text { Teachers } \\
(4)\end{array}$ \\
\hline \multicolumn{5}{|l|}{ Panel A: Relevant Stories } \\
\hline \multirow[t]{2}{*}{ Stories } & 0.075 & $0.594 * * *$ & 0.218 & $0.363^{* * *}$ \\
\hline & 0.154 & 0.200 & 0.179 & 0.135 \\
\hline \multirow[t]{2}{*}{ Stories Squared } & $-0.015 * *$ & $-0.031 * *$ & -0.018 & $-0.016 * *$ \\
\hline & 0.006 & 0.009 & 0.006 & 0.005 \\
\hline \multicolumn{5}{|c|}{ Panel B: Relevant Male Teacher Stories } \\
\hline \multirow[t]{2}{*}{ Male Stories } & $0.714^{*}$ & $1.090 * * *$ & $0.684 * *$ & $0.602 *$ \\
\hline & 0.401 & 0.367 & 0.319 & 0.347 \\
\hline \multirow[t]{2}{*}{ Male Stories Squared } & $-0.105^{* *}$ & $-0.151 * * *$ & -0.069 & -0.067 \\
\hline & 0.047 & 0.055 & 0.051 & 0.056 \\
\hline \multicolumn{5}{|c|}{ Panel C: Relevant Female Teacher Stories } \\
\hline \multirow[t]{2}{*}{ Female Stories } & -0.036 & 0.426 & 0.130 & 0.152 \\
\hline & 0.304 & 0.411 & 0.219 & 0.220 \\
\hline \multirow[t]{2}{*}{ Female Stories Squared } & -0.016 & -0.028 & -0.020 & -0.009 \\
\hline & 0.015 & 0.022 & 0.008 & 0.009 \\
\hline Observations & 8,361 & 22,031 & 8,361 & 22,031 \\
\hline
\end{tabular}

Source: QLFS 1993-2010 Notes: Estimates from a logit regression of individual decision to join a union on news stories. Reporting the marginal effects at mean. All coefficients and standard errors are multiplied by 100 for ease of interpretation. Estimates can be read a percentage change in probability. All estimates conditional on teacher characteristics Accusation stories are stories involving Allegations, Being Sued and Criminal Activity. Relevant Stories include both Extremely and Highly relevant news stories. Stories Regionally is a count for the number of news stories that originated in the region that the teacher resides in the previous 12 months. Standard errors in italics, clustered at the regional level. 
Appendix Table 5: Union Membership on Union Membership by News Coverage Period

\begin{tabular}{lcccccc}
\hline \hline News Coverage period & $\begin{array}{c}\text { In last 6 } \\
\text { months } \\
(1)\end{array}$ & $\begin{array}{c}\text { In last 12 } \\
\text { months } \\
(2)\end{array}$ & $\begin{array}{c}\text { In last 18 } \\
\text { Months } \\
(3)\end{array}$ & $\begin{array}{c}\text { In last 24 } \\
\text { Months } \\
(4)\end{array}$ & $\begin{array}{c}\text { In last 30 } \\
\text { Months } \\
(5)\end{array}$ & $\begin{array}{c}\text { In last 36 } \\
\text { Months } \\
(6)\end{array}$ \\
P(Union Membership) & $0.540^{* *}$ & $0.449 * * *$ & $0.521^{* * *}$ & $0.331^{* * *}$ & 0.141 & 0.065 \\
Relevant Stories & 0.260 & 0.149 & 0.107 & 0.119 & 0.103 & 0.104 \\
Regionally & $-0.058^{* * *}$ & $-0.026^{* * *}$ & $-0.024 * * *$ & $-0.014 * *$ & -0.005 & -0.001 \\
Relevant Stories & 0.019 & 0.007 & 0.004 & 0.005 & 0.004 & 0.004 \\
Regionally Squared & & & & & & \\
\hline Marginal Effect at & $0.472^{*}$ & $0.380^{* *}$ & $0.429^{* * *}$ & $0.258^{* *}$ & 0.112 & 0.055 \\
Mean & 0.261 & 0.150 & 0.425 & 0.204 & 0.106 & 0.109 \\
\hline
\end{tabular}

Teacher Characteristics

Regional Effects

Year Effects

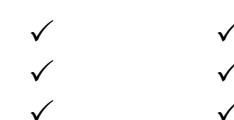

Observations

30,392

$30,392 \quad 30,392 \quad 30,392$

$\begin{array}{ll}\checkmark & \checkmark \\ \checkmark & \checkmark \\ \checkmark & \checkmark\end{array}$

$\checkmark$
$\checkmark$
$\checkmark$

$\checkmark$

30,392

30,392

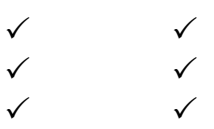

Source: QLFS 1993-2010 Notes: Reporting the marginal effects after transforming by $P(\widehat{U n l o}) *(1-$ $P(\widehat{\text { Unlon }}))$. All coefficients and standard errors are multiplied by 100 for ease of interpretation. Estimates can be read a percentage change in probability. Marginal effect at mean calculated by $\beta_{1}+2 \beta_{2} \overline{s_{J}}$. Accusation stories are stories involving Allegations, Being Sued and Criminal Activity. Relevant Stories include both Extremely and Highly relevant news stories. Stories Regionally is a count for the number of news stories that originated in the region that the teacher resides in the previous X months. Standard errors in italics, clustered at the regional level.

\section{Appendix Table 6: Union Membership on News Coverage of Accusations and Actual Allegations}

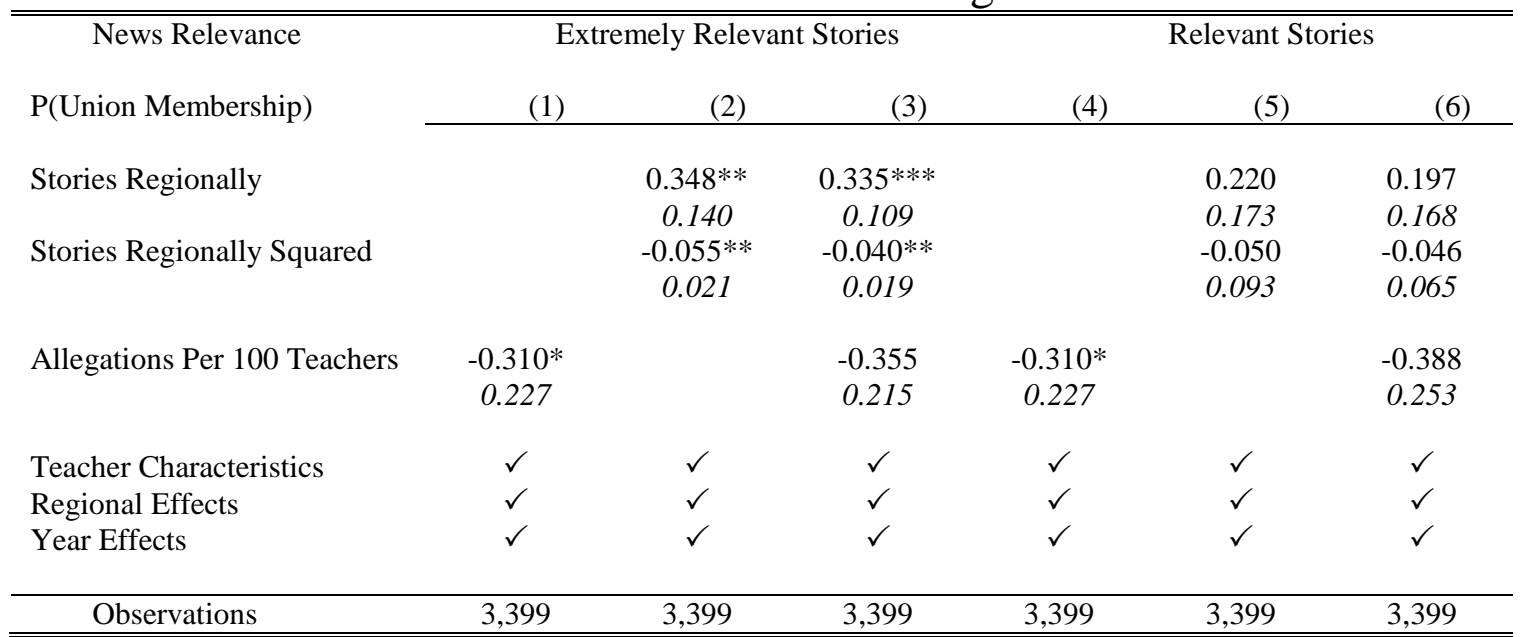

Source: QLFS 2008-2010 Notes: Estimates from a logit regression. Reporting the marginal effects All coefficients and standard errors are multiplied by 100 for ease of interpretation. Accusation stories are stories involving Allegations, Being Sued and Criminal Activity. Relevant Stories include both Extremely and Highly relevant news stories. Standard errors in italics, clustered at the regional level. 


\section{Appendix Figure 1 Union Density by Age Group over time}

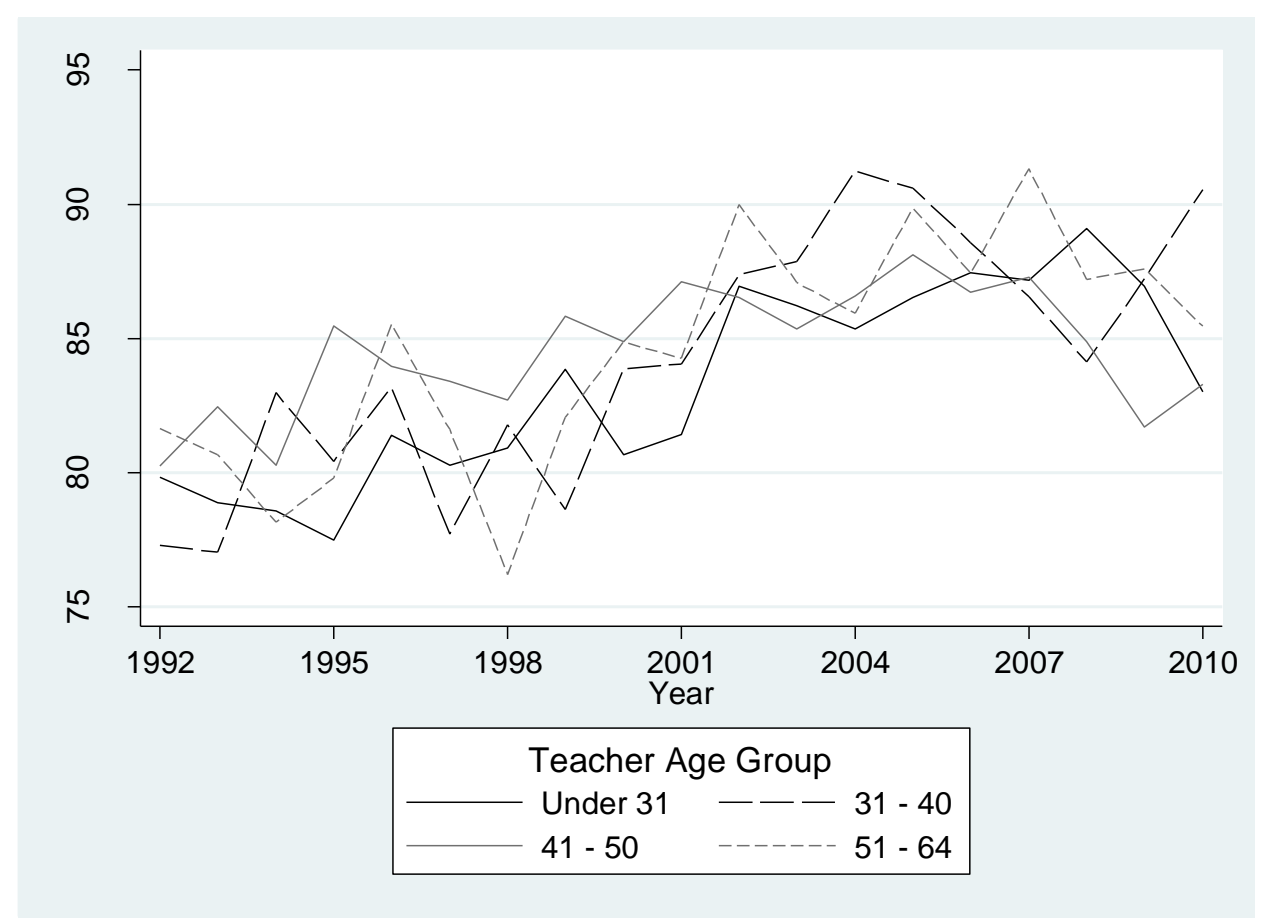

Source: QLFS 1992:2010 Notes: Annual union density based on mean union membership of teachers based on QLFS reporting year. 